\title{
Vive em mim toda Marielle Franco: repressão, resistência, arqueopoesia e a materialidade das vivências de mulheres negras
}

\author{
Lara de Paula Passos*
}

\begin{abstract}
PASSOS, Laura de Paula. Vive em mim toda Marielle Franco: repressão, resistência, arqueopoesia e a materialidade das vivências de mulheres negras. R. Museu Arq. Etn. 35: 79-102, 2020.
\end{abstract}

Resumo: Após o assassinato da vereadora, socióloga negra, feminista e defensora dos direitos humanos Marielle Franco, em 14 de março de 2018, começaram a eclodir diversas manifestações de repressão e resistência envolvendo sua imagem. O caso também aumentou a produção e circulação de materiais (físicos ou digitais) envolvendo o genocídio do povo preto e o feminicídio, que acontece em todo o país e atinge de forma particular as mulheres negras. Este trabalho propõe observar esse fenômeno específico enquanto estudo de caso, abordando também de forma ampliada e sob uma ótica antropológica, arqueológica e poética o panorama material que envolve as vivências de mulheres negras no que tange às questões de repressão e resistência.

Palavras-chave: Arqueologia; Arqueopoesia; Repressão e resistência; Descolonialidade.

Me disseram e repito: mulher negra não é só dor.

Falo não apenas para fazer coro a outras irmãs-guias

Mas pra que eu mesma escute

E me leve com meus próprios pés a um caminho [de cura

Que fuja de tanta coisa que atinge a mim.

O que eu chorei não teve medida

O que eu senti não tinha nome

Eu falo de tudo aquilo que eu tenho medo

Não me leve a mal, é que vive em mim toda

Marielle Franco

E eu me ergo depois de cada escombro

De cada tiro

De cada arrasto

De cada estrangulamento

$\mathrm{O}$ mundo parece pequeno

Perto de tanta coisa grande acontecendo

* Mestra e doutoranda em Antropologia - área de concentração em Arqueologia, UFMG.

<laradepaulapassos@gmail.com>
Com a gente, comigo, conosco

E eu nem falo só do sufoco

Do desespero, do aperto de mente

Do medo constante de que o próximo seja a gente Mais gente da nossa gente

Eu falo também de toda apropriação

De toda negação que a gente tem que resistir

Tô cansada

Exausta de tanto levar bala eu reclamando de barriga cheia

E ainda assim com um vazio dentro que me impede de seguir em frente com [tranquilidade

Porque

A cada esquina, a cada passo, com o passar da idade

$O$ rosto dela vai virando o meu

Eu que nem conheci pessoalmente

te conto como tem vivido as pessoas que ousaram [seguir em frente 
Vive em mim toda Marielle Franco: repressão, resistência, arqueopoesia e a materialidade das vivências de mulheres negras R. Museu Arq. Etn., 35: 79-102, 2020.

Te falo:

Não ficou grande por ter sido morta

Foi morta por ser gigante

E deixou um legado sem número adiante

E brotou para florescer

Então, enxergo que pra mim não há outro caminho

Outro destino

Que não ser fiel às areias do tempo

Me conecto ao processo ancestral e longínquo que [me exige

que eu não me perca de mim

Que eu não me afunde na dor

Que eu não me afogue em tristeza

Eu que sou correnteza

me uno a outras trajetórias líquidas

pra virarmos essa maré

Nos mantermos de pé

E juntas

Honremos Marielle

\section{Um nome que ecoa}

A s vezes um nome já diz tudo. Ao mesmo tempo, é impossível contar quantas coisas cabem dentro dele. Marielle Franco era mulher, negra, mãe, bissexual, ativista. Em si, muito mais do que isso e ainda assim tão perpassada por todas as coisas que a compunham em vida, sabendo bem se apresentar e reconhecer seu lugar de fala (Ribeiro 2019):

Marielle Franco é cria da favela da Maré. É socióloga formada pela PUC-Rio e mestra em Administração Pública pela Universidade Federal Fluminense (UFF). Sua dissertação de mestrado teve como tema: "UPP: a redução da favela a três letras". Trabalhou em organizações da sociedade civil, como a Brasil Foundation e o Centro de Ações Solidárias da Maré (Ceasm). Coordenou a Comissão de Defesa dos Direitos Humanos e Cidadania da Assembleia Legislativa do Rio de Janeiro (Alerj), ao lado de Marcelo Freixo. Tem 39 anos e foi eleita
Vereadora da Câmara Municipal do Rio de Janeiro pelo Psol. Mulher, negra, mãe, favelada, Marielle Franco foi a quinta vereadora mais votada no Rio de Janeiro nas eleições de 2016, com 46.502 votos.

Iniciou sua militância em direitos humanos após ingressar no pré-vestibular comunitário e perder uma amiga, vítima de bala perdida, num tiroteio entre policiais e traficantes no Complexo da Maré. Ao se tornar mãe aos 19 anos, de uma menina, Marielle também começou a se constituir como lutadora pelos direitos das mulheres e debater essa temática na periferia. As questões do feminismo, da luta contra o racismo, bem como a defesa dos direitos humanos nas favelas do pais modulam o perfil de seu mandato e seus projetos em busca de um modelo de cidade mais justo para todos e todas.

(Franco 2017: 89)

$\mathrm{O}$ interesse de Marielle pela sociologia urbana, pelos estudos de segregação socioespacial e violência urbana marcaram seu mandato: apresentou dezesseis projetos de lei enquanto vereadora, conseguindo a aprovação de sete dentre eles (Rocha 2018). Ocupou espaços de representatividade para a população feminina negra e LGBTQIA+ que ao longo da história nacional têm sido majoritariamente ocupados por homens brancos heterocisnormativos e com vasto acúmulo de capital. Assumiu em março de 2018 a função de relatora da Comissão da Câmara de Vereadores do Rio de Janeiro, criada para acompanhar a atuação dos militares na intervenção em favelas do Rio. Desde o dia 10 de março de 2018 a vereadora postava em suas redes sociais os abusos de autoridade policial contra civis no bairro Acari. Na véspera de sua morte, Marielle fez um tweet (FIGURA 1) mencionando o assassinato de um jovem no bairro e questionando "quantos mais vão precisar morrer para que essa guerra acabe?" 


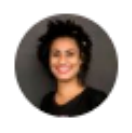

Marielle Franco @ @mariellefranco.13 de mar de 2018

Mais um homicídio de um jovem que pode estar entrando para a conta da PM. Matheus Melo estava saindo da igreja. Quantos mais vão precisar morrer para que essa guerra acabe?

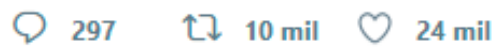

Fig. 1. Tweet de Marielle na véspera de seu assassinato. Fonte: Twitter.

Marielle foi executada a tiros no dia 14 de março de 2018 em seu carro no bairro Estácio de Sá, junto do motorista Anderson Pedro Gomes, enquanto voltava de uma roda de conversa intitulada "Jovens Negras Movendo Estruturas”, na Casa das Pretas, Lapa/RJ. Um carro emparelhou com o veículo da vereadora, contra o qual foram disparados treze tiros, atingindo Anderson e Marielle. No carro também estava a assessora Fernanda Chavez, que ficou ferida por estilhaços, mas sobreviveu. A placa do carro dos assassinos era clonada e a munição da arma disparada provinha de um lote vendido à Polícia Federal de Brasília em 2006 (Leitão 2018). Em março de 2019 foram presos dois acusados de participarem do crime: o policial militar reformado Ronnie Lessa e o ex-policial militar Élcio Queiroz, ambos suspeitos de integrarem organizações paramilitares, as milícias. No entanto, as investigações acerca do assassinato de Marielle seguem em aberto até o momento de produção deste texto, mais de 590 dias após a execução.

O impacto da morte de Marielle Franco foi gigante e inesperado, e desencadeou uma série de produções materiais e disputas de discurso. Este trabalho se dedicou a observar algumas das materializações desses desdobramentos, bem como a analisar as relações com a arqueologia urbana e os estudos descoloniais, utilizando, além disso, a abordagem arqueopoética. Discutem-se também os impactos na população negra e feminina, suas vivências e resistências.

\footnotetext{
Um grito na noite

Ao som de quatro tiros

Uma cai

E mil se levantam

Ouvem-se os ruídos
}

\author{
De chocalhos de serpentes à espreita \\ Que parecem recuar um pouco mais \\ a cada vela acesa \\ A cada corpo em marcha \\ Que sofre, chora, sangra \\ Mas não para \\ Senão para recolher os destroços \\ Velar mais um dos nossos \\ E seguir em romaria \\ Admiro a valentia \\ Das que escolhem dar ao coletivo \\ sua partilha \\ Sabendo o risco de também poder ser \\ $\mathrm{O}$ alvo encontrado \\ de alguma bala perdida \\ Munindo-se de coragem \\ Contra toda covardia \\ Por ideais de liberdade \\ De justiça e equidade \\ Que sustentam a força feminina
}

Quanto às estatísticas, o Brasil possui uma população majoritariamente feminina e, além disso, preta e parda (IBGE 2010). É, no entanto, um dos cinco países mais violentos do mundo para mulheres (Gustafson 2019) principalmente em se tratando de mulheres negras (Câmara dos Deputados 2018a) -, mantendo também altos números referentes à mortalidade (Carta Capital 2017) e encarceramento (Câmara dos Deputados 2018b) da população negra, bem como a desigualdade de acesso à educação (Ferreira 2018). Diante desse cenário, não é difícil perceber que a existência e resistência de uma mulher negra favelada na política desperta, simultaneamente, admiração e incômodo. A existência de minorias representativas de maiorias numéricas materializa a desigualdade vivenciada pela população 
brasileira, sob aspectos que tangem não somente o racial e o gênero, mas também o social.

É importante, portanto, ressaltar a crucialidade de um olhar engajado e situado diante dos fatos envolvendo o caso Marielle Franco. A partir de meu lugar de fala, perpassado por tantos marcadores similares aos de Marielle, comprometo-me com uma produção interseccional (Akotirene 2018) de conhecimento científico que não pode deixar de reconhecer diversas conjunturas que permeiam o contexto estudado. Um fazer científico localizado (Haraway 1995) é ao mesmo tempo um ato de produção e de denúncia, que se constrói em oposição à suposta neutralidade do ambiente acadêmico a fim de descortinar as injustiças imbricadas pelas opressões institucionalizadas.

A arqueologia é um campo da ciência que permite visualizar esses momentos de disputa discursiva, porém não sem alguma dificuldade. Ainda que possua uma fundação nitidamente colonial e imperialista, a partir da prática colecionista e como ferramenta hegemônica de dominação que contribuiu para construir os Estados-Nação na Europa (Bruno 1996), o tempo e a elaboração de uma narrativa científica positivista trouxeram à arqueologia ares de neutralidade. Com o aumento dos movimentos identitários e das lutas pelos direitos humanos e pautas sociais, a arqueologia também se viu impactada por estudos que se constroem à serviço de uma prática indisciplinada (Haber, 2011), comprometida, de resistência e crítica à colonialidade do saber (Ribeiro, 2017).

Esta pesquisa, portanto, encontrase alinhada aos estudos de arqueologia do mundo moderno e contemporâneo, bem como aos estudos descoloniais na arqueologia. Para sua produção também foram utilizados elementos da arqueologia urbana e da arqueologia da repressão e da resistência. São apresentados neste artigo alguns elementos materiais envolvendo o caso Marielle Franco, acrescidos de uma reflexão acerca das disputas político-discursivas envolvendo tais materialidades. O material observado foi adquirido por meio de uma coleta assistemática, mediante pesquisa virtual, doação espontânea de imagens feita por alguns indivíduos e prospecção em algumas áreas, principalmente universidades públicas em perímetros urbanos. Foi feita uma solicitação via redes sociais do envio de material por e-mail, o que contribuiu para parte considerável do levantamento. No pedido, foram requisitadas imagens cujo conteúdo apresentasse alguma materialidade envolvendo a pessoa de Marielle Franco, podendo ser objetos, cartazes, pichações etc. O material inclui também resultados de pesquisas on-line utilizando as hashtags \#MarielleFranco, \#MarielleVive e \#MariellePresente. Ao final, foram coletadas e analisadas cerca de 150 imagens, divididas por tipo de materialidade retratada (digital/analógica, cartaz, pichação, objeto etc.) e período (data da morte, um ano após o assassinato etc.), sendo algumas delas apresentadas ao longo do texto para exemplificar suas respectivas categorias.

\section{Antes da bala: uma disputa discursiva de [tempos atrás}

"Da história instrumental dos que são feridos por alguma injustiça remota, qualquer que seja a retórica, os inocentes serão julgados pelo marco de um parágrafo escrito em tinta preta sobre um papel perverso que destila o ódio em suaves prestações.

À espera de um grito que cure

o ressentimento do mundo

ou mesmo ressalte o caráter transitório da ideologia:

Pátria partida e nenhum elo que a una [novamente.

Uma mulher é silenciada no país da escravidão." (Fernanda Fatureto)

Antes da apresentação dos dados levantados pela pesquisa é importante contextualizar rapidamente o cenário no qual emergiu o caso Marielle. A atual conjuntura política no Brasil é, sem dúvida, um reflexo da trajetória histórica da construção da nação. Seus capítulos mais recentes, no entanto, têm 
influência direta na elaboração dos discursos do fenômeno analisado.

Em um passado não tão recente ocorreu a colonização europeia, que dizimou a população indígena e engendrou a diáspora africana compulsória e a escravidão, alicerçando o país em bases racistas e genocidas. Com a instauração da abolição (1888) sem nenhum tipo de medida paliativa, as populações escravizadas e seus descendentes se viram à margem da sociedade, em situação de desamparo governamental, subempregos e falta de acesso ao saneamento básico e à educação de qualidade. Assim, a desigualdade foi se solidificando no Brasil, criando uma constante tensão entre as forças de manutenção do status quo e dos grupos privilegiados e as de resistência e lutas por justiça social. Com o tempo, aderiu-se às categorias de direita e esquerda (Silva, 2014; Tarouco \& Madeira, 2013) herdadas da Revolução Francesa ${ }^{1}$ : a primeira, em países ocidentais do final do século XX, é construída sobre bases tradicionalistas, nacionalistas e conservadoras; a segunda, sobre a defesa de pautas sociais, direitos humanos, ambientalistas e de igualdade.

A vitória de um partido de esquerda por treze anos consecutivos nas eleições presidenciais foi criando com o tempo uma tensão cada vez maior com a oposição, gestando (junto de outros fatores) as manifestações

1 Durante a primeira fase da Revolução Francesa (1789. 1799), na Assembleia Nacional Constituinte montada para criar a nova Constituição, aqueles sentados à direita do presidente da assembleia eram "defensores da consciência da Constituição”, antigos partidários do rei, enquanto aqueles sentados à esquerda eram os "inovadores" simpatizantes da revolução. Com o tempo a utilização do termo foi se alterando, porém manteve-se a associação da esquerda à luta pelos direitos dos trabalhadores e a direita ao conservadorismo e à elite. "Dentro dessa visão, ser de esquerda presumiria lutar pelos direitos dos trabalhadores e da população mais pobre, a promoção do bem estar coletivo e da participação popular dos movimentos sociais e minorias. Já a direita representaria uma visão mais conservadora, ligada a um comportamento tradicional, que busca manter o poder da elite e promover o bem estar individual" (Tarouco \& Madeira 2013: 151). de 2013, que culminaram no golpe de 2016, dividindo o país de forma abrupta entre os dois grandes grupos-modelo. Marielle, filiada ao Partido Socialismo e Liberdade (Psol), era uma militante de esquerda. Segundo o relatório da Anistia Internacional de agosto de 2017, o Brasil é o país das Américas que mais mata defensores de direitos humanos (Dias, 2018). Esses fatos são cruciais para compreender as dinâmicas discursivas envolvendo sua imagem.

\section{A virtualidade: materializações virtuais e construções de discursos}

\author{
Do virtual ao real \\ a tecnologia do infinito \\ mesmo o que se enterra \\ segue sendo visto \\ o luto é tão mais doído \\ quando prolongado a um eterno \\ velório público, coletivo \\ choro na beira de um caixão à distância \\ e me sinto ao lado, na borda, na ânsia \\ de estar perto daquela \\ que nunca verei ao vivo, viva \\ e como pode a lonjura analógica \\ não ser páreo \\ para a proximidade patológica \\ que interliga todas \\ as nascidas de Luzia? \\ o digital é real \\ a tecnologia é finita \\ pois ainda não inventaram formas \\ de trazer de volta \\ o vigor de uma flor \\ que já foi partida
}

A partir da observação dos gráficos do Google Trends sobre pesquisas feitas ao nome de Marielle Franco ao longo dos anos e por localização/região (mundial e nacional), é possível observar aumento abrupto da demanda de informações, também acompanhado pelo aumento da produção de materiais envolvendo a figura da vereadora: 


\section{Google Trends}

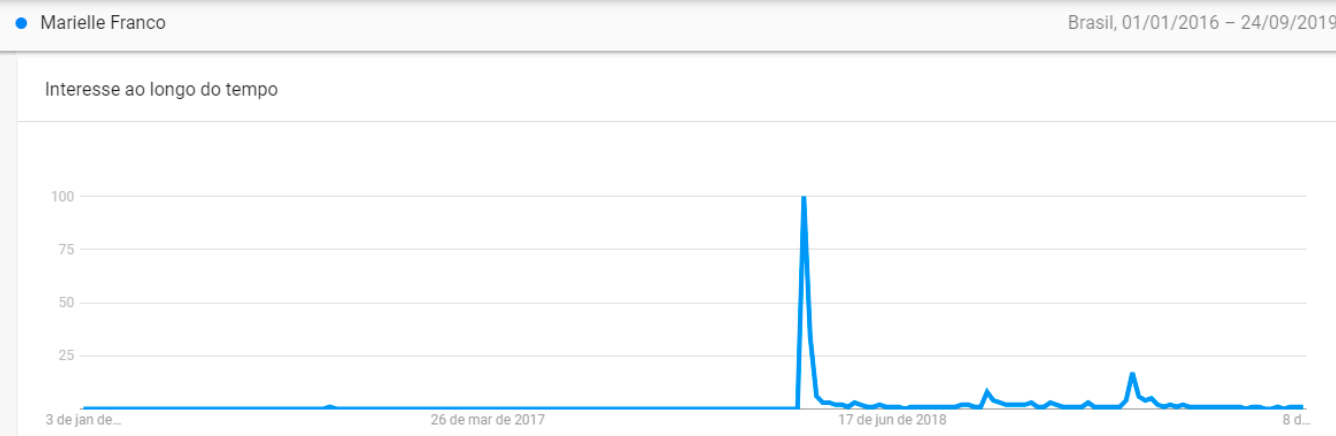

Fig. 2. Gráfico de frequência de pesquisa na web no Brasil pelo termo "Marielle Franco" no período de janeiro de 2016 a setembro de 2019 .

Fonte: Google Trends.

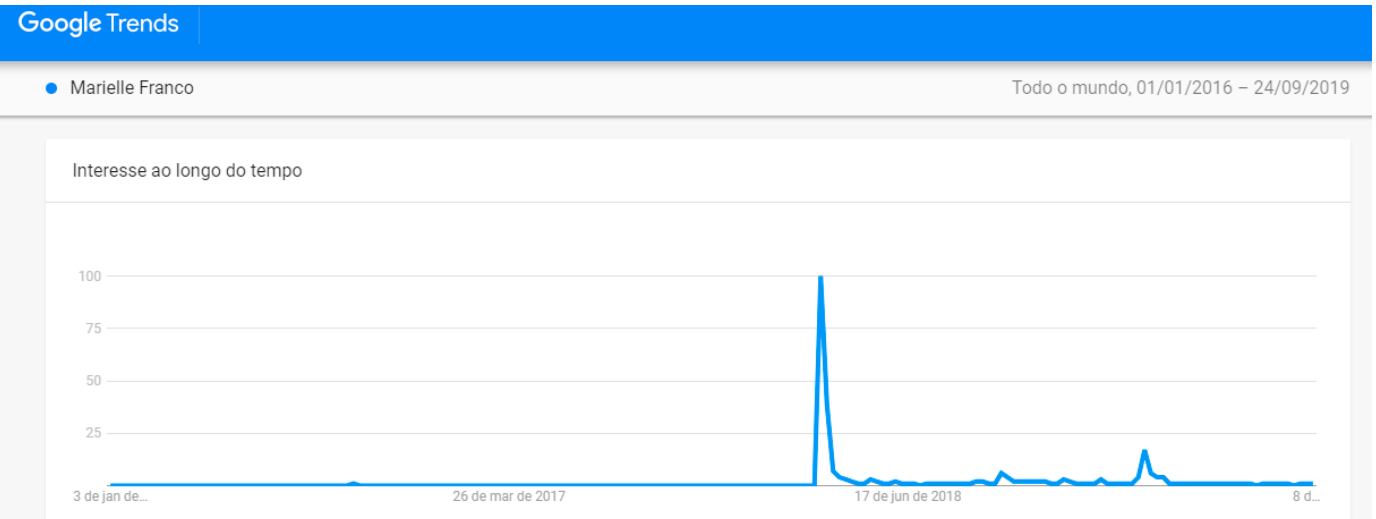

Fig. 3. Gráfico de frequência de pesquisa na web no mundo pelo termo "Marielle Franco" no período de janeiro de 2016 a setembro de 2019.

Fonte: Google Trends.

Tanto no gráfico nacional (FIGURA 2) como no mundial (FIGURA 3), há três picos de maior movimentação de pesquisas. $\mathrm{O}$ primeiro, e mais alto, data de 14 de março de 2018, dia da morte de Marielle. O segundo (e menor), do dia 4 de outubro de 2018, quando

2 A placa foi quebrada por Daniel Silveira, policial militar e deputado federal pelo Rio de Janeiro, e Rodrigo Amorim, deputado estadual no Rio de Janeiro, ambos eleitos pelo Partido Social Liberal (PSL). Em entrevista, Rodrigo Amorim declarou: "[estamos] cumprindo nosso dever cívico, removemos a depredação e restauramos a placa em homenagem ao grande marechal [...] Preparem-se, esquerdopatas: no que depender de nós, seus dias estão contados" (Marques 2018). foi quebrada a placa em homenagem à vereadora colocada na Cinelândia, Rio de Janeiro ${ }^{2}$. O terceiro se refere ao dia 14 de março de 2019, um ano após a morte de Marielle. A repercussão inicial estrondosa foi apresentada em levantamento da Diretoria de Análises de Políticas Públicas da Fundação Getulio Vargas (FGV), que afirma que das $22 \mathrm{~h}$ da quarta-feira (14 de março de 2018) até as $18 \mathrm{~h}$ da sexta-feira (16 de março de 2019) ocorreram em apoio a Marielle 84,6 mil tuítes em inglês e 133 mil em espanhol (Deister 2018). 


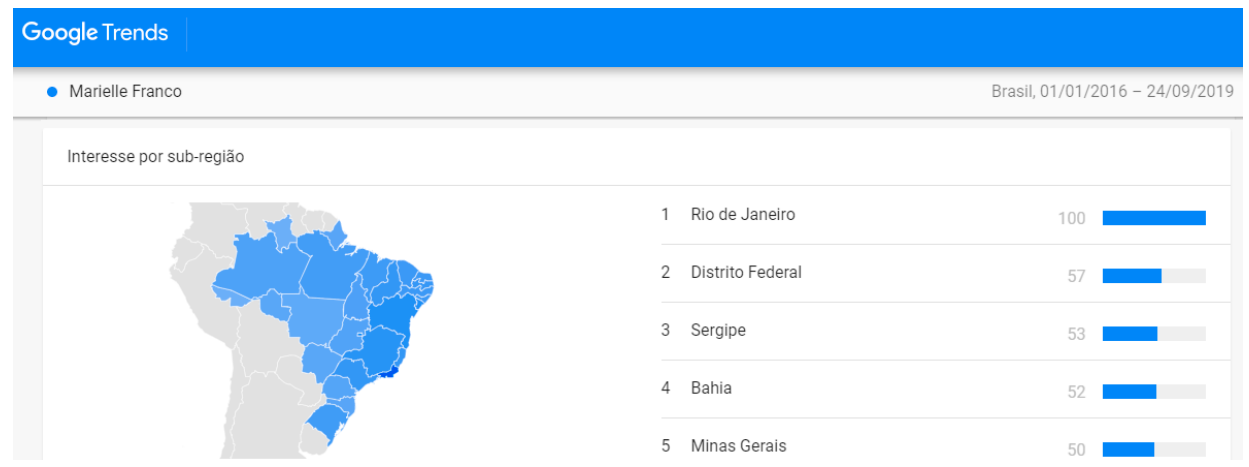

Fig. 4. Gráfico de frequência de pesquisa na web pelo termo "Marielle Franco" no período de janeiro de 2016 a setembro de 2019 por sub-região do Brasil.

Fonte: Google Trends.

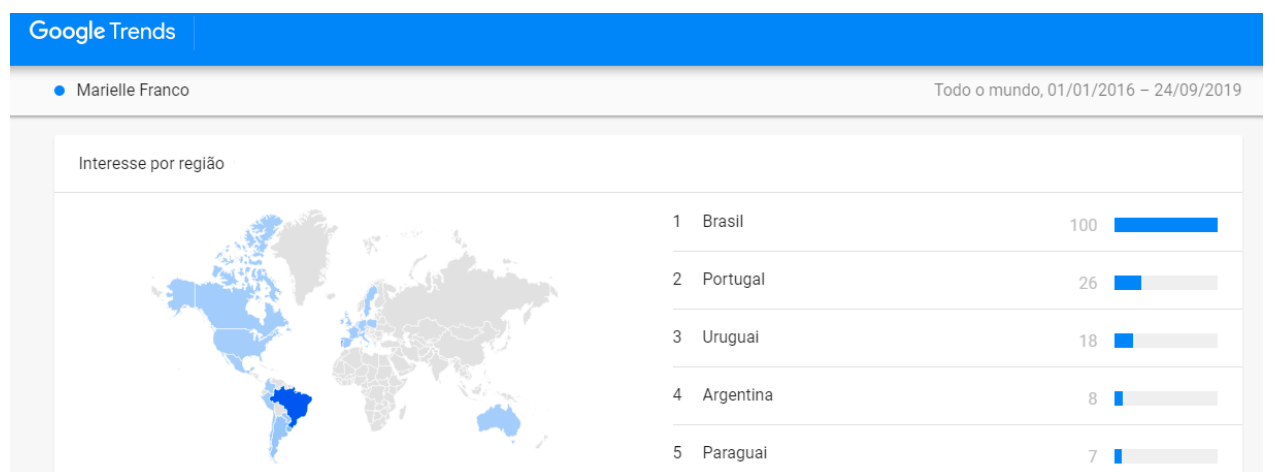

Fig. 5. Gráfico de frequência de pesquisa na web pelo termo "Marielle Franco" no período de janeiro de 2016 a setembro de 2019 por região do mundo.

Fonte: Google Trends.

Os gráficos detalhados por região do Brasil e pelos países também apresentam dados interessantes. O primeiro (FIGURA 4) mostra que o local de maior quantidade de pesquisas é o Rio de Janeiro, estado de nascimento, mandato e morte da vereadora. No gráfico mundial (FIGURA 5) é possível observar (em azul) a ocorrência de pesquisas na América, Europa e Oceania. Isso ilustra parte do alcance das notícias referentes à sua figura, bem como a relevância de seu assassinato para o cenário político não só nacional, mas também internacional, tendo sido inclusive condenado pela Organização das Nações Unidas (ONU).

Foram observadas três grandes categorias de manifestações virtuais que se sucederam à notícia da execução de Marielle: a produção de notícias sobre a morte, as homenagens (charges, textos e postagens públicas nas redes sociais) e a proliferação de notícias falsas (fake news). As duas últimas categorias foram analisadas enquanto construção de discurso e disputa de interesses de uso da imagem.

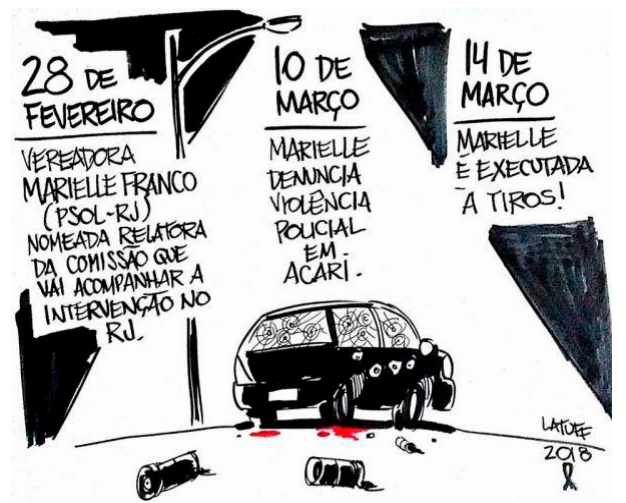

Fig. 6. Charge referente ao assassinato de Marielle Franco, 2018.

Fonte: Latuff. 
Vive em mim toda Marielle Franco: repressão, resistência, arqueopoesia e a materialidade das vivências de mulheres negras R. Museu Arq. Etn., 35: 79-102, 2020.

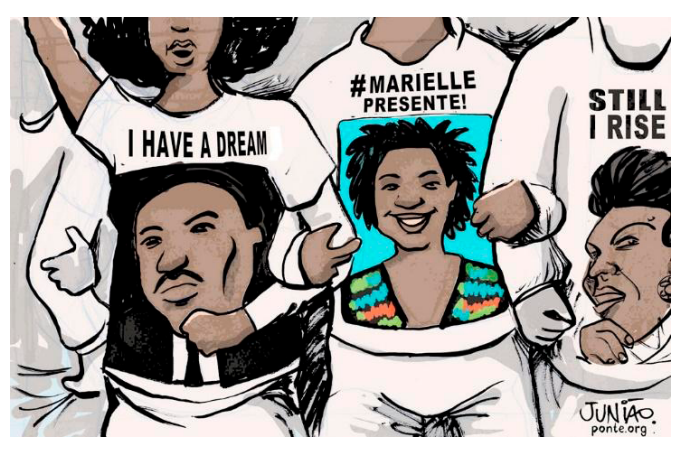

Fig. 7. Charge referente ao assassinato de Marielle Franco, 2018.

Fonte: Junião.

\section{MARIELLE FRANCO}

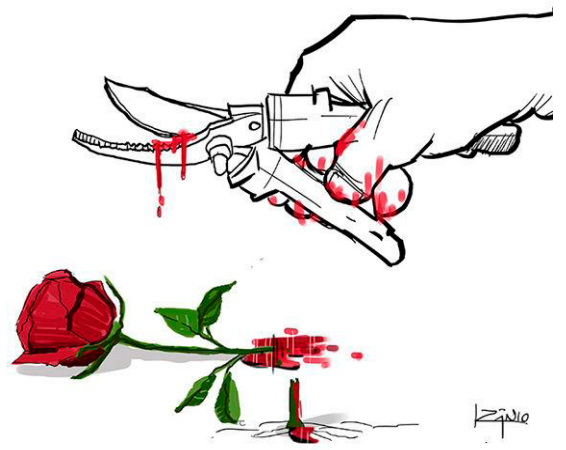

Fig. 8. Charge referente ao assassinato de Marielle Franco, 2018.

Fonte: Izânio.

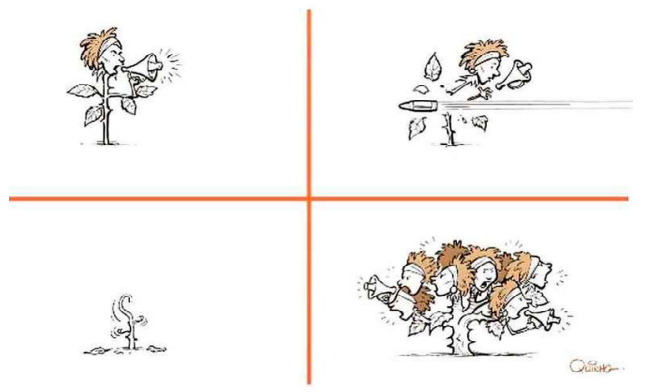

Fig. 9. Charge referente ao assassinato de Marielle Franco, 2018.

Fonte: Quinho.

De início, charges e cartuns denunciaram o caráter político da execução de Marielle
Franco, apresentando sua trajetória de denúncia das injustiças policiais cometidas no estado do Rio de Janeiro (FIGURA 6) e associando sua imagem a outras figuras emblemáticas da luta pelos direitos das pessoas negras no mundo, como Martin Luther King Jr. (também assassinado) e Maya Anjelou (FIGURA 7). Além disso, começaram a surgir as primeiras associações de Marielle à imagem de uma planta podada de forma abrupta e violenta (FIGURAS 8 e 9) que, por sua vez, faz germinar outras vozes (FIGURA 9). Essa alusão pôde ser observada diversas vezes ao longo do tempo, culminando na recorrente alusão a Marielle como "semente".

De outro lado, as manifestações virtuais contrárias à sua memória produziam também imagens carregadas de discursos diversos:

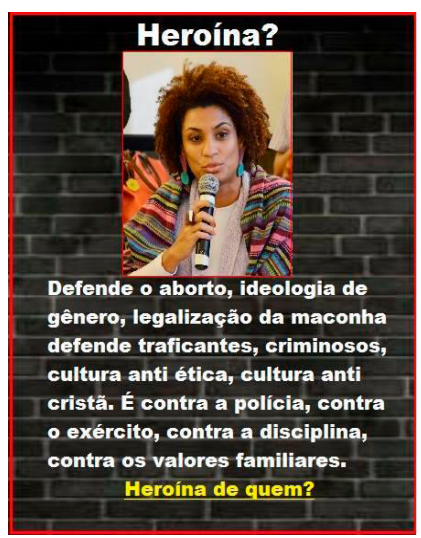

Fig. 10. Imagem de difamação de Marielle Franco veiculada em redes sociais.

Fonte: Google Images.

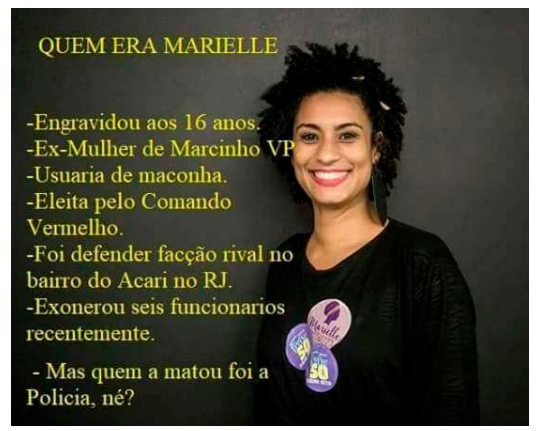

Fig. 11. Imagem de difamação de Marielle Franco contendo informações falsas compartilhada em redes sociais. Fonte: Google Images. 
Esta categoria de imagens observadas foram chamadas de fake news. Imagens contendo informações falsas sobre a vida de Marielle (FIGURAS 10 e 11), como as exemplificadas, contêm em si dois objetivos: o primeiro, descredibilizar sua figura enquanto heroína e, segundo, culpabilizá-la em alguma medida pela própria morte, justificada por tais más condutas atribuídas a ela. A figura de Marielle coloca em riste as bandeiras pelas quais ela lutava (que também foram muito provavelmente a sua causa-mortis). Isso faz com que a disputa extrapole a representação individual dela enquanto sujeita e escale para o nível de embate de ideologias. Admirar e homenagear a figura de Marielle significa, então, relacionar-se de forma positiva com o universo da esquerda do qual ela participa. Portanto, cabe aos grupos opositores combater sua imagem enquanto símbolo, atacando seu significado.

$\mathrm{MBL}$ - Movimento Brasil Livre

Sim, todos os homicídios no Brasil são políticos. Todos os mais de 60

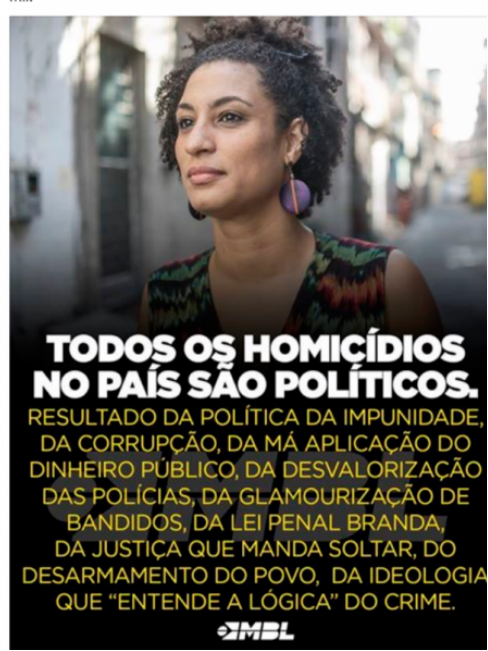

Fig. 12. Imagem de difamação de Marielle Franco contendo informações falsas, compartilhada em redes sociais.

Fonte: Página do Facebook do Movimento Brasil Livre (MBL).

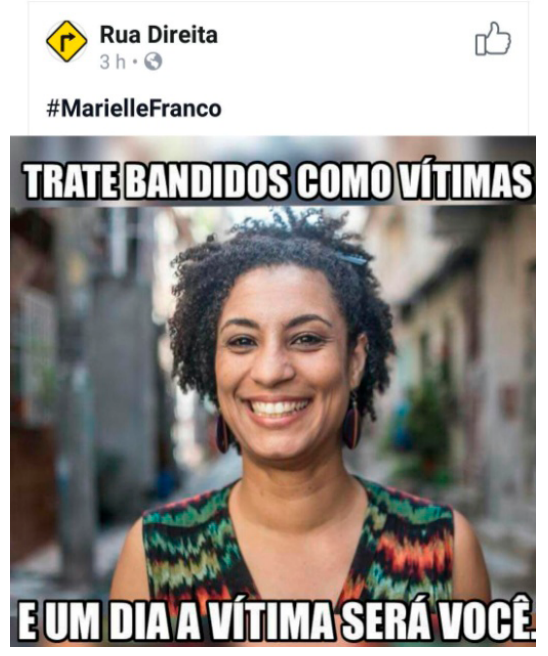

Fig. 13. Imagem de difamação de Marielle Franco contendo informações falsas, compartilhada em redes sociais.

Fonte: Página do Facebook Rua Direita.

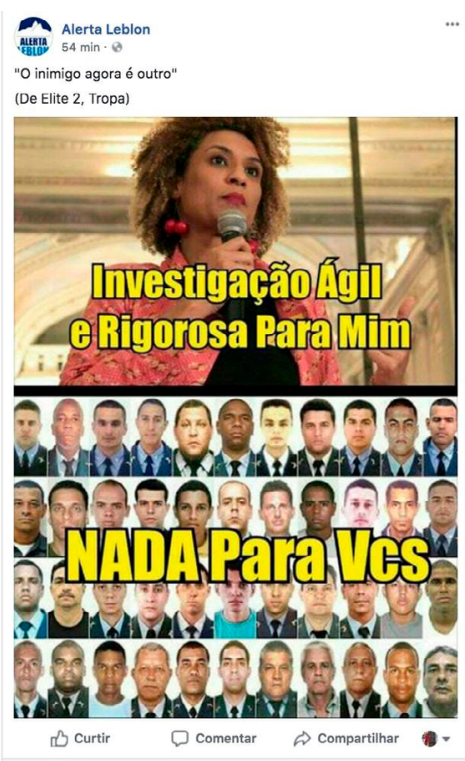

Fig. 14. Imagem de difamação de Marielle Franco, compartilhada em redes sociais.

Fonte: Página do Facebook Alerta Leblon. 


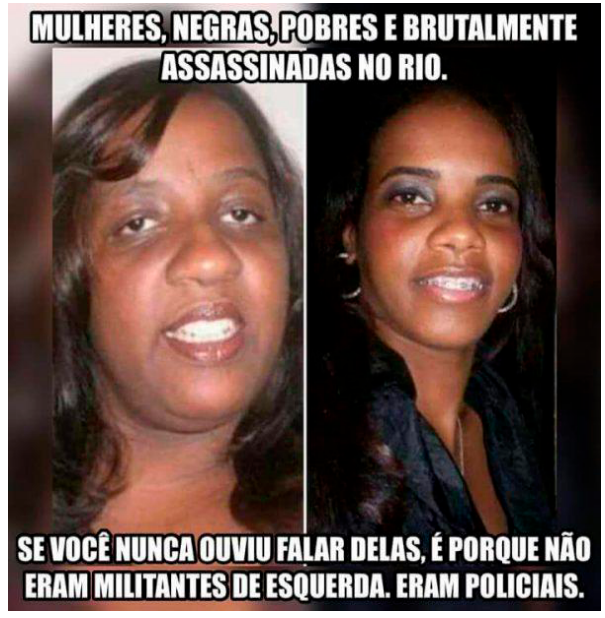

Fig. 15. Imagem de difamação de Marielle Franco contendo informações falsas, compartilhada em redes sociais.

Fonte: Google Images.

Uma vez comprovado que as balas usadas para assassinar Marielle e Anderson faziam parte de lotes de munição vendidos para a Polícia Federal (O Globo 2018b), além da suspeita da ligação da milícia do Rio de Janeiro com o crime, a tensão criada entre defensores e combatentes da polícia elevou-se de forma visível.

As postagens em redes sociais (Facebook, Instagram) e aplicativos de mensagens (Telegram, WhatsApp) ilustram bem a construção argumentativa sobre Marielle produzida pela oposição.

Duas ideias foram observadas dentre as mais pautadas: primeiro, a de esvaziamento do caráter de exceção do assassinato da vereadora e, segundo, a falsa simetria que colocava de um lado as mortes de policiais e, de outro, a morte e condução da investigação do caso da vereadora.

Nas imagens que ilustram a primeira ideia é possível ver a banalização do uso de termos como "homicídio político", a fim de postular que "todos os homicídios no país são políticos" (FIGURA 12) e, portanto, nenhum seria mais influenciado por esse fator do que outro, conduzindo o assassinato de Marielle para a esfera do comum, em contraste com caráter de singularidade que a esquerda lhe conferiu. Nas FIGURAS 12 e 13 são apontados motivos que explicariam o assassinato, como a "vitimização/ glamourização" de bandidos, atribuídos à prática de Marielle em vida devido a sua luta por uma política de segurança pública menos racista, mais inclusiva e justa, que criticava diretamente a polícia (em especial as Unidades de Polícia Pacificadora - UPPs) do Rio de Janeiro (Franco 2018).

Quanto à segunda ideia, outros elementos imagéticos são usados, além das fotos de Marielle: imagens de policiais assassinados em serviço. A fim de sustentar a dicotomia polícia algoz versus polícia vítima, o argumento aponta um suposto favoritismo, um privilégio do caso Marielle em relação aos demais casos de homicídio, em especial aqueles envolvendo policiais. A crítica, no entanto, cai em sua própria armadilha argumentativa ao empregar de maneira anônima a imagem de pessoas que "nunca foram mencionadas", utilizandoas de forma esvaziada e sem contexto. Ignora propositalmente, além disso, a atuação de Marielle Franco na Comissão de Direitos Humanos (CDH) (Perez 2018) da Assembleia Legislativa do Rio de Janeiro, onde atendeu e amparou dezenas de familiares de policiais civis e militares vítimas de violência. Ao contrário do discurso vazio das fake news, este trabalho comprometia-se seriamente com os nomes, as histórias, os casos e os familiares dessas pessoas.

De fato, todas as mortes importam. E é uma pena que sejam tantas as vítimas de violência no Brasil, que acaba por se tornar impossivel dar o espaço merecido a todas elas, tanto na mídia, como em protestos, como em nossos trabalhos, ou falas diárias. Também é bastante doloroso pensar na possibilidade de que estejamos caminhando cada vez mais em direção a uma Guerra Civil em relação as nossas ideologias, por conta da tão acirrada dicotomia Direita $\times$ Esquerda, que tem visado apenas a humilhação ou eliminação do grupo que julgamos diferente de nós. No entanto, não podemos esquecer que existem pessoas de ambos os lados lutando por um Brasil melhor e menos violento, e Marielle era uma delas. 
Em sua dissertação de mestrado, Marielle falou dos vários policiais assassinados brutalmente no Brasil, inclusive Fabiana Aparecida de Souza, 30 anos e Alda Rafael Castilho, 27 anos; jovens policiais negras assassinadas no Rio [e cujos rostos estampam a FIGURA 15]. Pode ser que muitas das pessoas que compartilharam a imagem na internet não soubessem o nome delas, mas Marielle sabia. A vereadora escreven 139 páginas de texto analisando a presença das Unidades de Polícia Pacificadora (UPPs) nas favelas do Rio de Janeiro e suas implicações. Ela também prestava auxilio jurídico e psicológico às famílias de vítimas de homicídios e policiais vitimados há 10 anos (Schirmer \& Dalmolin 2018: 13).

Esses discursos de ódio, é importante saber, não foram construídos exclusivamente sob o anonimato de imagens não assinadas. Várias figuras públicas expuseram suas opiniões nas redes sociais, como o então delegado da polícia civil de plantão da delegacia da mulher de Pernambuco Jorge Ferreira, que postou em seu Facebook: "Se envolve com o narcotráfico, vira mulher de bandido, troca de facção criminosa, é assassinada pelos 'mano', aí vem a esquerda patética pôr a culpa nas instituições policiais. Vá se fu, dona Marielle. Já foi tarde. Detesto bandido e quem os defende odeio mais ainda". O delegado foi afastado por processo administrativo. A desembargadora do Tribunal de Justiça do Rio (TJ/RJ), Marília Castro Neves, postou no Facebook logo após a notícia da morte

A questão é que a tal Marielle não era apenas uma "lutadora"; ela estava engajada com bandidos! Foi eleita pelo Comando Vermelho e descumpriu "compromissos" assumidos com seus apoiadores. Ela, mais do que qualquer outra pessoa "longe da favela" sabe como são cobradas as dividas pelos grupos entre os quais ela transacionava. Até nós sabemos disso. A verdade é que jamais saberemos ao certo o que determinou a morte da vereadora mas temos certeza de que seu comportamento, ditado por seu engajamento politico, foi determinante para seu trágico fim.
Qualquer outra coisa diversa é mimimi da esquerda tentando agregar valor a um cadáver tão comum quanto qualquer outro ${ }^{2}$.

Alberto Fraga, deputado federal pelo DF postou em seu Twitter dois dias após a morte da vereadora: "Conheçam o novo mito da esquerda, Marielle Franco. Engravidou aos 16 anos, ex-esposa do Marcinho VP, usuária de maconha, defensora de facção rival e eleita pelo Comando Vermelho, exonerou recentemente 6 funcionários, mas quem matou, foi a PM". Foi aberto um processo de cassação do mandato de Alberto, arquivado em maio de 2018 (G1 2019). O policial militar Jonatas Guedes e o vice-presidente da Ordem dos Advogados do Brasil (OAB) de Salto/SP Flávio Garcia fizeram comentários ridicularizando a morte da vereadora pelo Facebook (Saconi 2018). Em um grupo sobre a cidade de Salto/SP, os comentários mencionavam uma hamburgueria paulista que possuía em seu cardápio um sanduíche nomeado "Maria da Penha”, que, segundo a descrição, continha "muito repOLHO ROXO" (com destaque de cor roxa nas letras maiúsculas). "Quero o X-Marielle", escreveu o cabo, a quem o vice-presidente da $O A B$ questionou: "Muitas azeitonas?", gíria conhecida como sinônimo de projéteis, em referência aos utilizados para assassinar a vereadora, morta com quatro tiros na cabeça. Ainda que tenham lançado notas, nem a $\mathrm{OAB}$ nem a polícia militar de Salto moveram nenhum tipo de ação contra os envolvidos, que posteriormente vieram a público pedindo desculpas. Este tipo de discurso promove o chamado assassinato moral de Marielle Franco (Dias 2018), uma vida cuja representatividade está ao lado do signo de sua morte (Guimarães-Silva 2018).

Estas primeiras categorias de manifestações demonstram um pouco o que foram as dinâmicas cibernéticas iniciais envolvendo o caso Marielle Franco. As materializações, tanto pessoais quanto coletivas, no entanto, não se limitaram à esfera virtual, ganhando tônus a partir das manifestações públicas envolvendo a figura de Marielle.

2 Disponível em: $\langle$ https://bit.ly/31oEpli $>$. Acesso em: 20/09/2019. 
Vive em mim toda Marielle Franco: repressão, resistência, arqueopoesia e a materialidade das vivências de mulheres negras R. Museu Arq. Etn., 35: 79-102, 2020.

O discurso que transborda para o ritual: as manifestações de 2018 e 2019

\author{
"astuta a morte, \\ que prega peças; \\ quantas vezes ouviste, \\ quando foste criança, \\ menina, não mexas no vespeiro!
}

mas a todas as meninas pretas

dizem as mesmas tolices;

e a todas as meninas, afinal.

até o dia em que,

incomodados com tanta ousadia,

executam-nas a céu aberto,

devolvendo-as ao silêncio.

tua voz, no entanto, semeia

e o silêncio jamais será o mesmo,

cravejado de mil gritos."

(Recado - Ana Elisa Ribeiro)

A notícia do assassinato de Marielle provocou manifestações (O Globo 2018a) no Brasil e no mundo. Seu ápice aconteceu nos dias 15 de março de 2018 (dia seguinte à sua morte) e 14 de março de 2019 (aniversário de um ano da morte). Nestes dois momentos, duas perguntas tornaram-se emblemáticas: "Quem matou Marielle Franco?" e "Quem mandou matar Marielle Franco?" Ainda que as manifestações de 2019 tenham ocorrido após alguns desenvolvimentos na investigação do caso, com a acusação de Élcio Vieira de Queiroz e Ronnie Lessa pelo assassinato, pode-se dizer que pouco se avançou, mesmo com as recentes informações que ligam o caso inclusive à família do atual presidente da república (Marreiro 2019).

Nos protestos os discursos virtuais foram materializados em diversos suportes, como bandeiras, cartazes, faixas, camisetas, instalações artísticas e pinturas corporais. Durante a pesquisa foram recolhidas imagens de manifestações no Brasil, Argentina, Uruguai, Estados Unidos, França, Portugal, Suíça, Itália, Alemanha, Inglaterra, Espanha e Austrália.

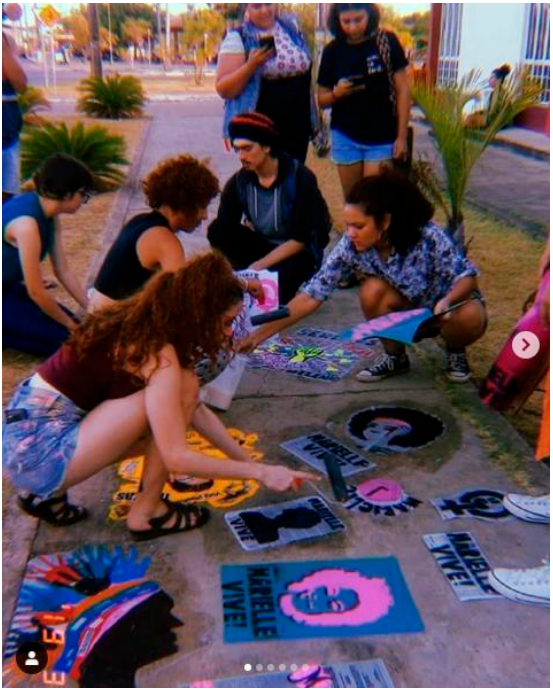

Fig. 16. Preparativos para manifestação em solidariedade a Marielle Franco na UFRR/RR, 15 de março de 2018.

Fonte: Fotografia de Marina Freitas.

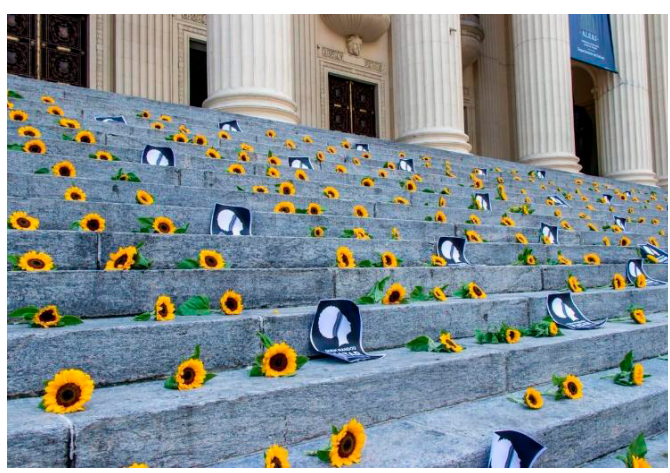

Fig. 17. Homenagem a Marielle na escadaria do Palácio Tiradentes, sede da Assembleia Legislativa do Rio de Janeiro/RJ, 14 de março de 2019. Foram espalhados 365 girassóis representando os 365 dias sem a vereadora.

Fonte: Fotografia de Tarcísio Mota.

A eclosão de diversos núcleos de protesto ao redor do mundo trouxe à tona a revolta não apenas pelo assassinato, mas também por toda a estrutura conjuntural que permite a condução escusa das investigações e o contexto histórico 
de opressões que entrecruza este processo. O crime, portanto, é encarado como machista, misógino e racista, mas também como um atentado à presença de mulheres na democracia (Fernandes \& Carvalho 2018: 126).

O grito do concreto: pichações e interações urbanas

\author{
Te vi em cada esquina \\ Em cada muro pichado com seu nome \\ Andei muito \\ corri mundo \\ e não importava onde \\ você aparecia \\ se em spray, lambe, caneta ou tinta \\ sua lembrança sempre vinha \\ seu rosto espelho-amiga \\ ainda me fita \\ Sei que me habita \\ E enquanto houver luta \\ Não há fuga \\ Permanecerás viva
}

Além das manifestações datadas, outras formas de expressão foram se materializando ao longo do tempo em diferentes espaços. Esses protestos são bastante diversificados enquanto técnica, mensagem e suporte, como se pode ver a partir do levantamento. $O$ estudo deste material observou os níveis narrativos, elementos técnicos utilizados para construir/ transmitir essa mensagem e a materialidade pela qual ela foi expressa.

Ao final da coleta foram analisados vestígios de imagens enviadas dos estados de Minas Gerais (Ouro Preto, Mariana, Cláudio, São João del-Rei, Sete Lagoas e Belo Horizonte), São Paulo (São Paulo, Campinas, Guarulhos, São José do Rio Preto, Petrópolis), Rio de Janeiro (Rio de Janeiro, Niterói), Sergipe (Aracaju, Laranjeiras), Ceará (Crato, Fortaleza), Roraima (Boa Vista), Rio Grande do Sul (Porto Alegre) e Pernambuco (Recife), além das cidades de Lisboa (Portugal) e Buenos Aires (Argentina).

A maior parte do material coletado é oriunda de perímetros urbanos de alta densidade, localizados principalmente no Sudeste (Belo Horizonte, Rio de Janeiro e São Paulo). Também foi observada alta recorrência de manifestações em instituições de ensino (escolas, universidades).

Dentre este material, foram observadas algumas ocorrências mais frequentes, aqui descritas em quatro técnicas: o lambe (cartaz em papel afixado por meio de cola ou grude, que pode ser disposto espacialmente a fim de formar mosaicos), o grafite (técnica de desenho sobre superfície utilizando tinta spray, pincel ou uma combinação de técnicas), o estêncil (impressão feita a partir de molde vazado em cujas partes recortadas se aplica o pigmento) e a escrita livre (pichação com caneta, tinta spray ou pincel atômico). Cada tipo de intervenção tem uma abordagem diferente: algumas prezam pela composição imagética e outras pelo discurso escrito.

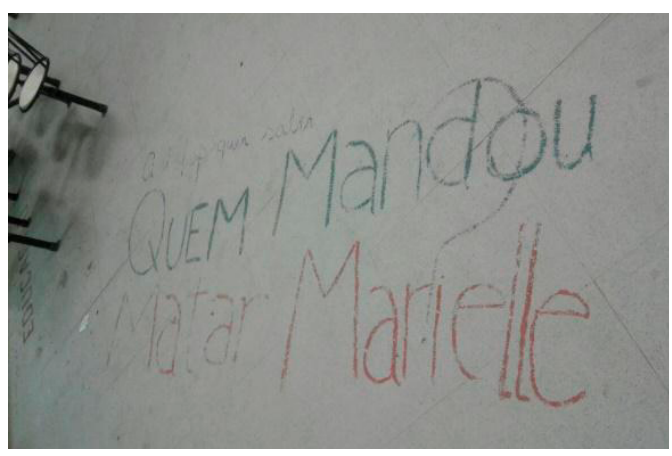

Fig. 18. Grafismo no chão da Unifesp em Guarulhos. Fonte: Fotografia de Alice Soares, 2019.

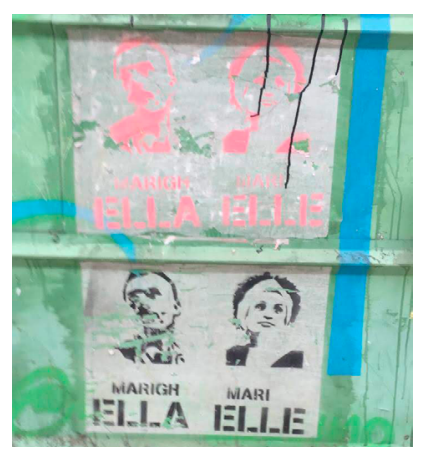

Fig. 19. Estêncil Marighella Marielle, av. Paulista, São Paulo.

Fonte: Fotografia de Lilian Cordeiro, 2019. 
Vive em mim toda Marielle Franco: repressão, resistência, arqueopoesia e a materialidade das vivências de mulheres negras R. Museu Arq. Etn., 35: 79-102, 2020.

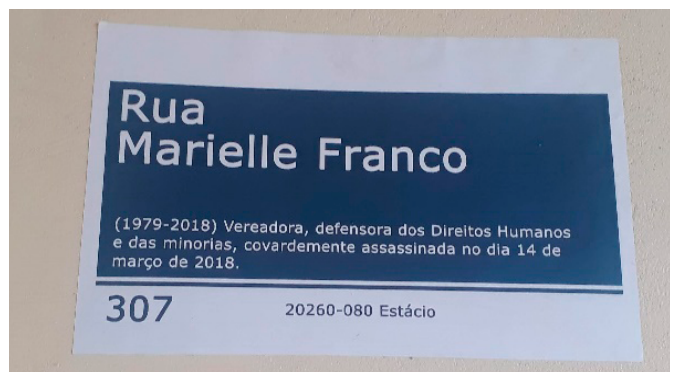

Fig. 20. Lambe da placa em homenagem a Marielle colado na UFS, Campus Laranjeiras.

Fonte: Fotografia de Lara Passos, 2019.

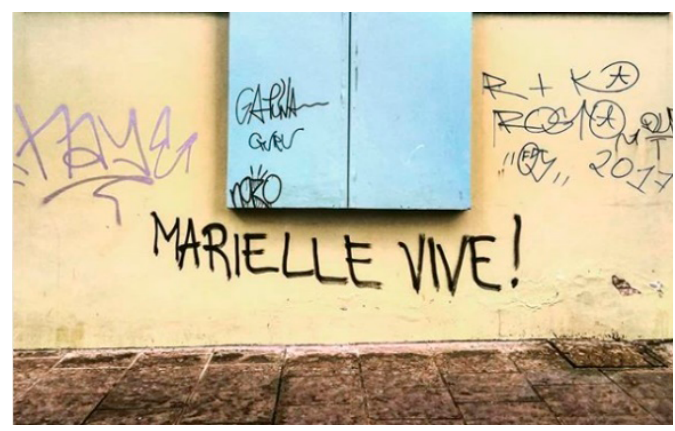

Fig. 21. Pichação com tinta spray, Porto Alegre. Fonte: Fotografia de Pablo Terres, 2019.

Na FIGURA 18 podemos ver escrito "Quem Mandou Matar Marielle?" em tinta no chão da Unifesp, Guarulhos. A partir de um estudo prévio de intervenções urbanas oriundas de manifestações e ocupações (Passos \& Mota 2019), pude reconhecer este vestígio como o negativo da produção de faixas: na ausência de algo impermeável por baixo, a tinta vaza pela trama do tecido, deixando rastros de sua produção. Esta intervenção relaciona-se, portanto, a outro objeto e a outro acontecimento, e pode estar ligada às manifestações pela morte de Marielle.

A FIGURA 19 mostra uma aplicação em estêncil que relaciona a figura de Marielle à de Carlos Marighella, guerrilheiro comunista morto no período da ditadura. Os paralelos entre Marielle e outros ícones do pensamento de esquerda mostram o caráter político de sua representação figurativa, que se estende para além de sua imagem individual, expondo também toda sua luta e seus ideais, compartilhados por outras pessoas em outros tempos e espaços.

O lambe feito a partir da reprodução da placa gerada no Rio de Janeiro da "Praça Marielle Franco” em Sergipe, no campus Laranjeiras da Universidade Federal de Sergipe (UFS) (FIGURA 20), demonstra um pouco do alcance desse discurso e sua importância enquanto posicionamento político. Falar de Marielle é sair do neutro e colocar-se ao lado de suas causas, por sua memória e contra seu apagamento. Algumas dessas intervenções inclusive combatem diretamente as forças políticas atuais, como se pode observar nos seguintes vestígios:

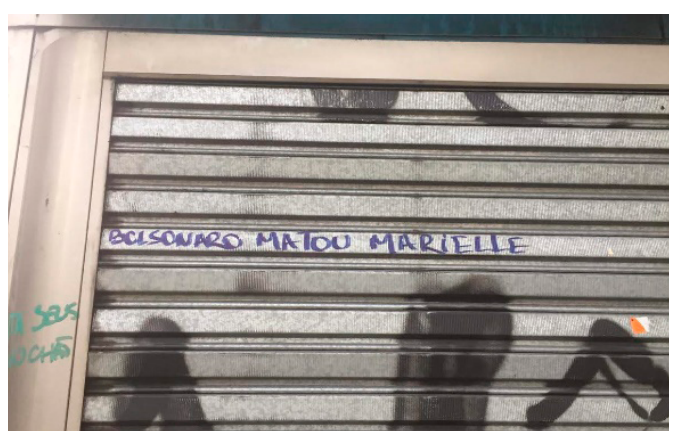

Fig. 22. Escrito livre com pincel atômico "Bolsonaro Matou Marielle", São Paulo.

Fonte: Fotografia de Lilian Cordeiro, 2019.

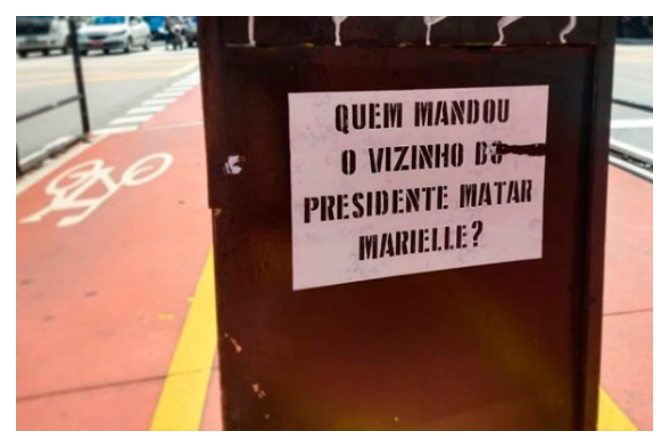

Fig. 23. Lambe "Quem mandou o vizinho do presidente matar Marielle?”, av. Paulista, São Paulo.

Fonte: Fotografia de Jap0nega. 


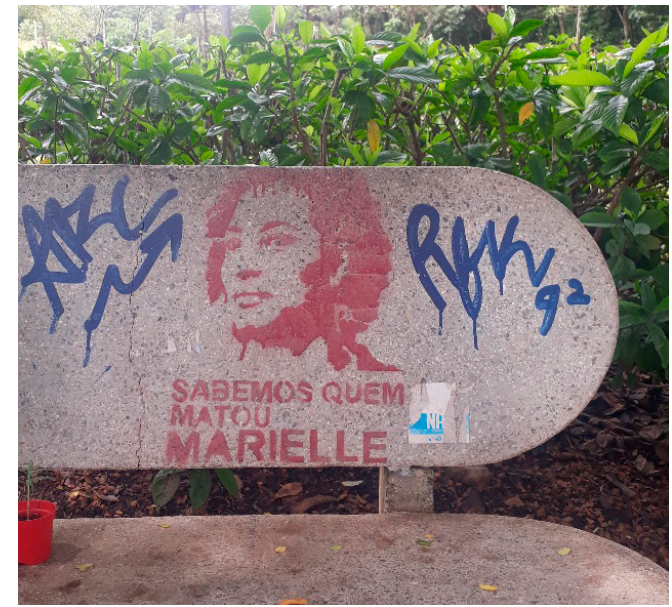

Fig. 24. Estêncil "Sabemos quem matou Marielle", UFMG, Belo Horizonte, 2018.

Fonte: Fotografia de Lara Passos.

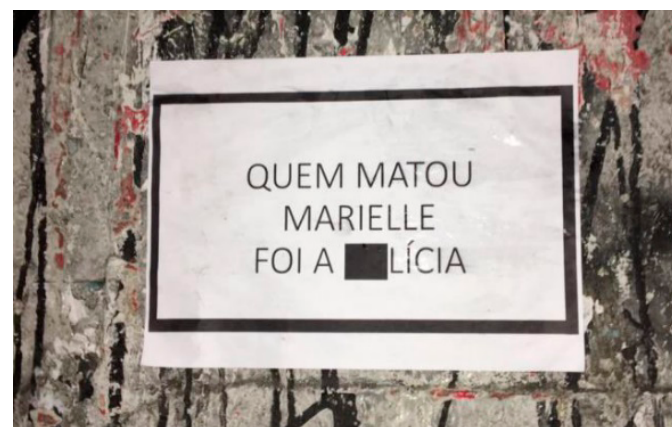

Fig. 25. Lambe "Quem matou Marielle foi a [llícia". Fonte: Mariana Silva Jorge.

Na primeira imagem (FIGURA 22) a frase "Bolsonaro matou Marielle" feita com pincel atômico liga de forma direta a morte de Marielle ao atual do país e a sua família (ao referir-se ao sobrenome). Esta ligação pode ser interpretada figurativamente: sua figura e os valores conservadores de direita que ele representa ocasionaram a morte da vereadora; ou de forma literal: uma acusação do envolvimento da família Bolsonaro no assassinato de Marielle Franco. Leituras similares podem ser feitas para os vestígios das FIGURAS 23 e 24. Na FIGURA 25 é interessante observar como o sujeito de enunciação escolhe passar a mensagem a partir da interação direta com quem lê, censurando o prefixo e permitindo à leitura preencher essa lacuna, de modo que se deduza uma ambiguidade, além de uma proximidade entre as possíveis inferências (milícia ou polícia).

Foi interessante observar no material recolhido a ocorrência de interações antagônicas envolvendo algumas intervenções. A arqueologia urbana vem falando sobre as disputas de poder nas interações na/ com a cidade, pensando a forma pela qual as diversas subjetividades vivenciam os espaços compartilhados (Carvalho 2013; Souza 2013). Vemos, no entanto, uma camada que excede a questão do interesse individual (da pessoa que intervém) em contraste à utilização do espaço público (onde a intervenção acontece). Esta camada se apresenta a partir do conflito ideológico-discursivo entre agentes individuais, que pode ser ilustrado com alguns exemplos (FIGURAS 26, 27 e 28).

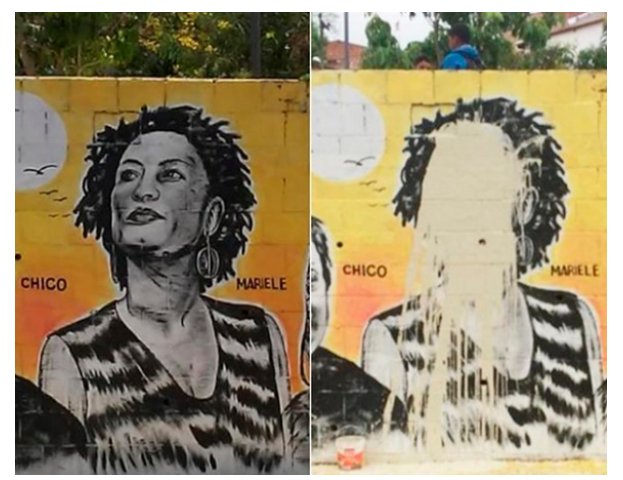

Fig. 26. Grafite de Marielle impactado, Crato, Ceará, 2019.

Fonte: Fotografia de Rafaela Dias.

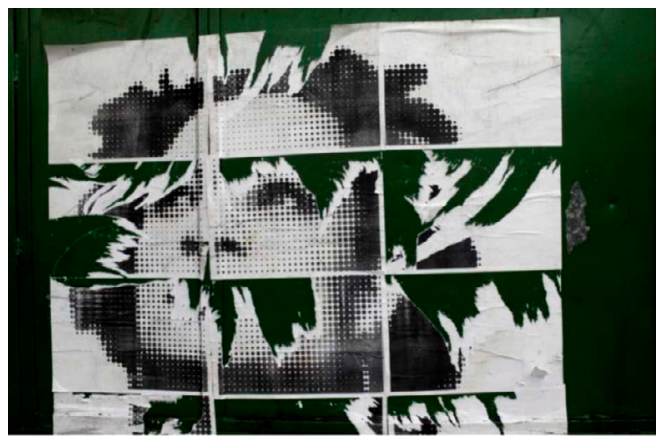

Fig. 27. Mosaico em lambes rasgado, Rio de Janeiro, 2019. Fonte: Fotografia de Ricardo Moraes. 
Vive em mim toda Marielle Franco: repressão, resistência, arqueopoesia e a materialidade das vivências de mulheres negras R. Museu Arq. Etn., 35: 79-102, 2020.

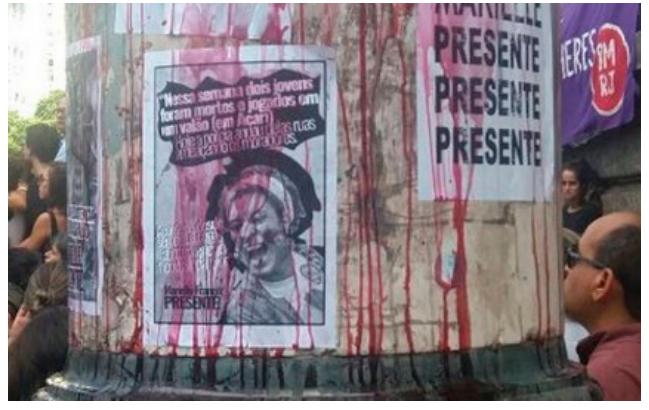

Fig. 28. Lambes alvejados de tinta, Rio de Janeiro, 2019.

Fonte: Fotografia de Ricardo Moraes.

Diversos lambes e pichações foram sobrepostos ou danificados na tentativa de remover as intervenções prévias. Esse tipo de ação demonstra o interesse de um segundo agente em anular o discurso proferido pelo primeiro interventor, indicando assim uma posição contrária não apenas à imagem de Marielle, mas ao que ela representa.

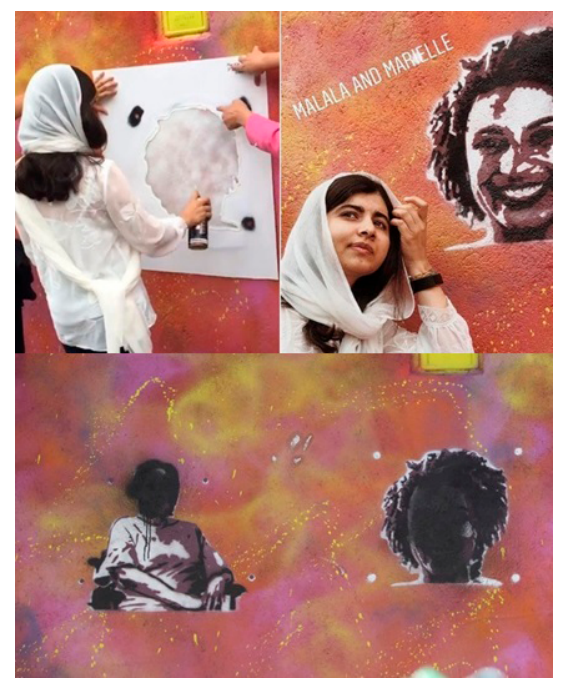

Fig. 29. Malala fazendo Estêncil de Marielle e Maria da Penha e estêncis impactados, Rio de Janeiro, 2018. Fonte: Fotografia de Luisa Dorr.

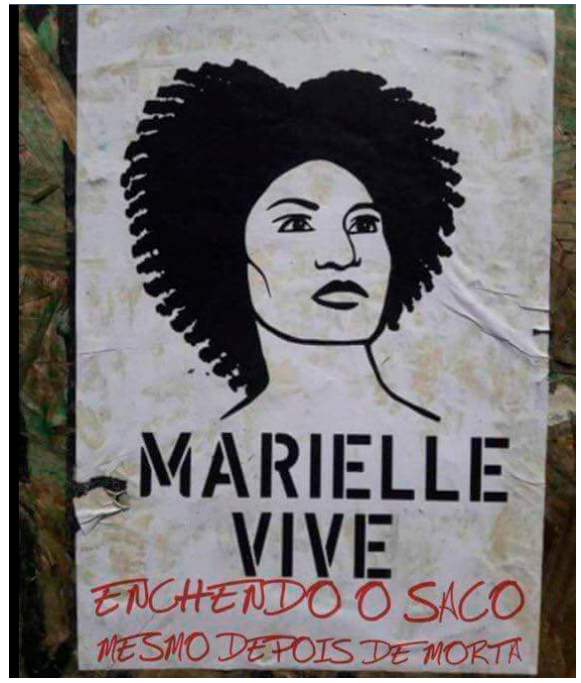

Fig. 30. Cartaz sobreposto de escrita livre em pincel atômico, Rio de Janeiro, 2018.

Fonte: Fotografia de Jesse Lopes.

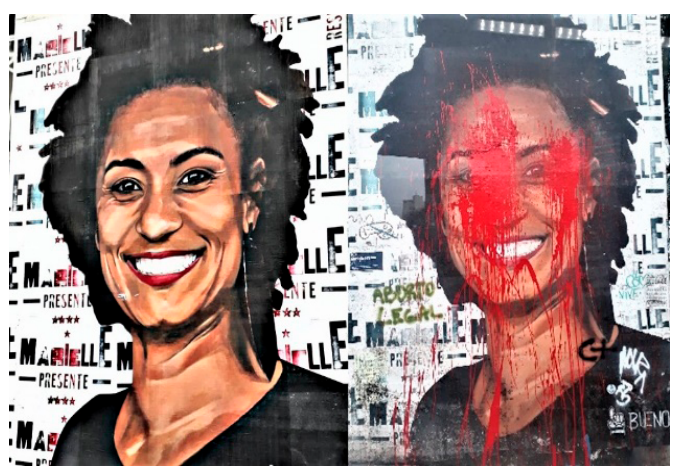

Fig. 31. Painel de Marielle, São Paulo, 2018.

Fonte: Fotografia de Lara Passos.

Em junho de 2018 a comunidade Tavares Bastos/RJ recebeu a visita da ativista e ganhadora do Nobel da Paz (2014) Malala Yousafzai, que fez grafites (G1 Rio 2018) de Marielle Franco e Maria da Penha com a Rede Nami, coletivo de mulheres da comunidade. 
Em dezembro do mesmo ano os grafites foram cobertos por spray preto. Câmeras de segurança puderam captar a imagem de um homem responsável pelo ato (IG São Paulo 2018) (FIGURA 29). Também no Rio de Janeiro foi encontrada outra interação de sobreposição, contendo uma mensagem mais explícita, observada na Figura 30, em que o lambe contendo os dizeres "Marielle Vive" foi impactado com o escrito "enchendo o saco mesmo depois de morta" em caneta vermelha. A adesão da frase deixa nítida a opinião de quem a colocou, evidenciando tensionamentos entre as duas narrativas, pró e contra a figura da vereadora e o que ela representava.

Em São Paulo, algumas interações chamam muita atenção. A primeira, ilustrada na Figura 31, ocorreu a partir da sobreposição de jatos de tinta vermelha em um mosaico de lambes com o rosto de Marielle. O impacto visual gerado por essa composição é assertivo, trazendo àquelas e àqueles que a avistam uma memória direta de seu assassinato.

A intervenção na arte feita por Bueno de início poderia ser vista como parte da obra, uma forma do artista de denunciar a violência sofrida por Marielle. No entanto, sabendo que esta é uma ação posterior não autorizada pelo artista, a sobreposição ganha outra interpretação, a tentativa de apagamento, de reiteração da violência. Outros casos de sobreposição puderam ser observados na avenida Paulista, onde lambes contendo a imagem do rosto de Marielle foram impactados com bigodes e outras características caricaturais, ridicularizando a figura da vereadora.

\section{Outros suportes, mesmas lutas?}

A representação da figura de Marielle não se circunscreveu apenas aos muros $\mathrm{e}$ construções de concreto da cidade. Além destes suportes, outros diversos foram sendo notados ao longo da pesquisa conforme emergiam com o passar do tempo. Foi interessante observar como a mudança de suporte alterou também a forma como cada mensagem é passada, bem como seus impactos, na medida em que o plano de expressão afeta a significação da informação emitida. $\mathrm{O}$ contexto de produção ou de utilização desses objetos também é de suma importância na análise de seus significados.

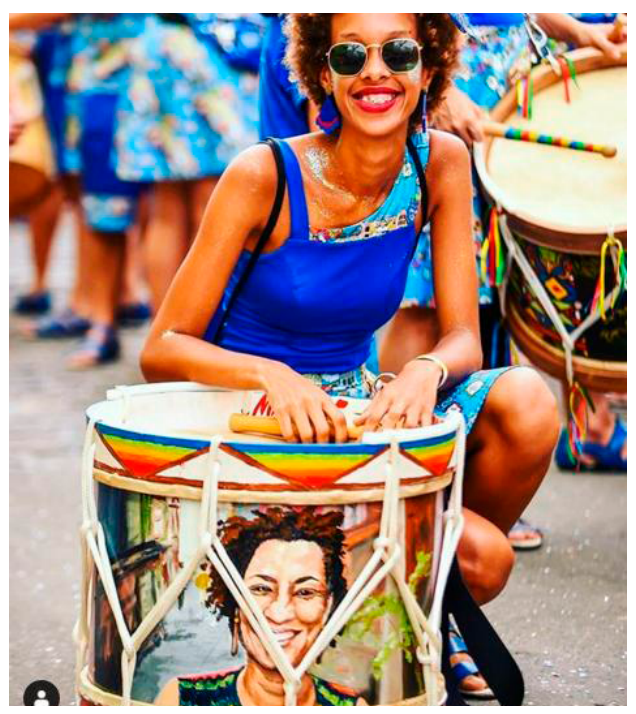

Fig. 32. Pintura de Marielle em corpo de tambor utilizado pelo Grupo Paranambuca em Recife, 2019.

Fonte: Fotografia do Grupo Paranambuca.

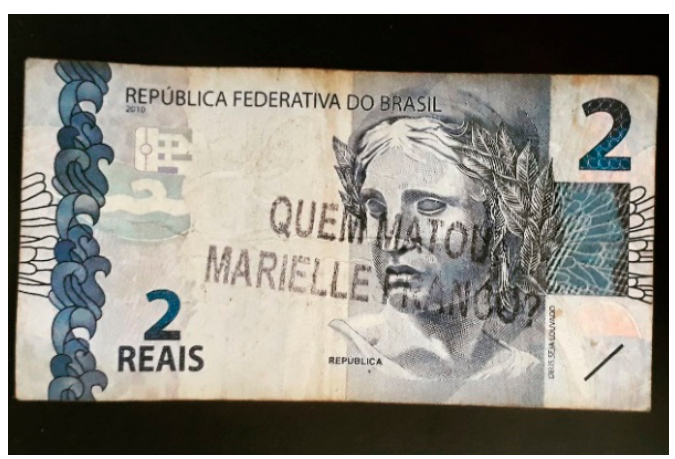

Fig. 33. Cédula carimbada com os dizeres "Quem matou Marielle Franco", 2018.

Fonte: Fotografia de Lara de Paula Passos. 
Vive em mim toda Marielle Franco: repressão, resistência, arqueopoesia e a materialidade das vivências de mulheres negras R. Museu Arq. Etn., 35: 79-102, 2020.

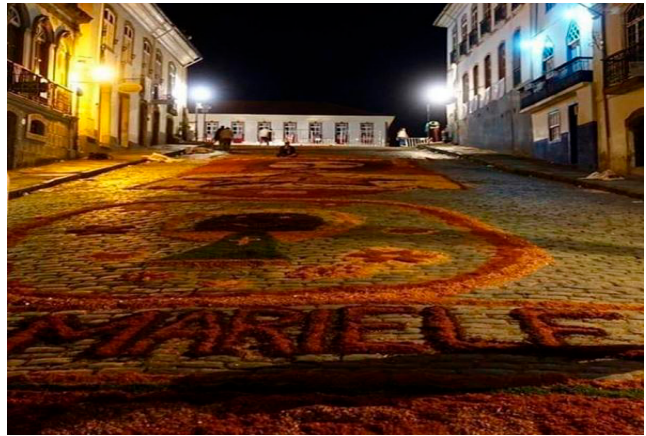

Fig. 34. Tapete de serragem feito durante o festejo católico da Procissão de Ramos em Ouro Preto, 2018.

Fonte: Fotografia de Sara Azevedo.

Na FIGURA 32, o tambor com a imagem do rosto da vereadora é utilizado em cortejos de diferentes ritmos (maracatu, caboclinho, afoxé, ciranda, coco de roda, mangue, samba, samba reggae, frevo canção, salsa) por um grupo artístico em Pernambuco. Tais manifestações culturais são, além disso, celebrações afro-brasileiras que contêm em si elementos de resistência, ancestralidade e tradição, afirmando também a negritude de forma positiva, mesmo perante as mazelas históricas do racismo. Relacionar a figura de Marielle a este tipo de ambiente cria uma narrativa não apenas de denúncia, mas de alegria, esperança e memória viva.

A cédula carimbada com a frase "Quem matou Marielle Franco?” (FIGURA 33), por sua vez, remete a outro contexto, também histórico, porém nada festivo. A peça é uma referência direta às notas de um cruzeiro carimbadas com a frase "Quem matou Herzog?" produzidas em 1975, relacionadas ao suicídio forjado do jornalista Vladimir Herzog durante a ditadura civil-militar.

Na FIGURA 34 é possivel observar o escoamento da discussão política para a esfera religiosa, em homenagem feita a Marielle durante a produção do tapete de serragem para a Procissão de Ramos, evento religioso de alta importância para o mundo católico, principalmente em cidades históricas como Ouro Preto. O mosaico, no entanto, foi desfeito por policiais civis locais antes da procissão, sob a alegação de que, em um evento religioso, não deveriam ser colocadas menções de nenhum cunho político ou partidário ${ }^{3}$, demonstrando a permanência do conflito de narrativas que circunda a figura de Marielle.

É importante mencionar também os perigos da apropriação de discurso envolvendo a imagem da vereadora, e de lutas sociais em geral, no que tange à comercialização de objetos.

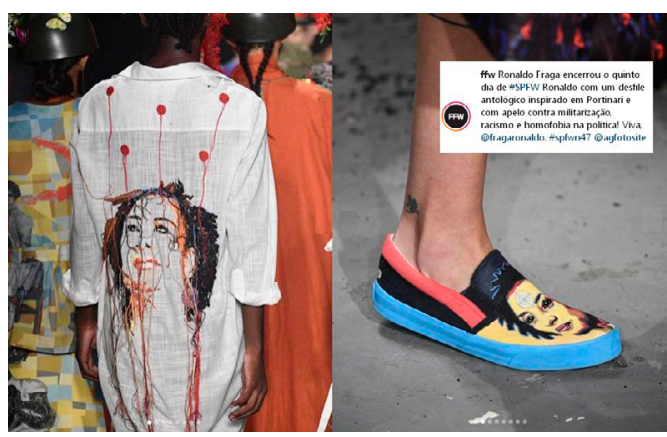

Fig. 35. Peças produzidas por Ronaldo Fraga em desfile da São Paulo Fashion Week, 2019.

Fonte: Instagram.

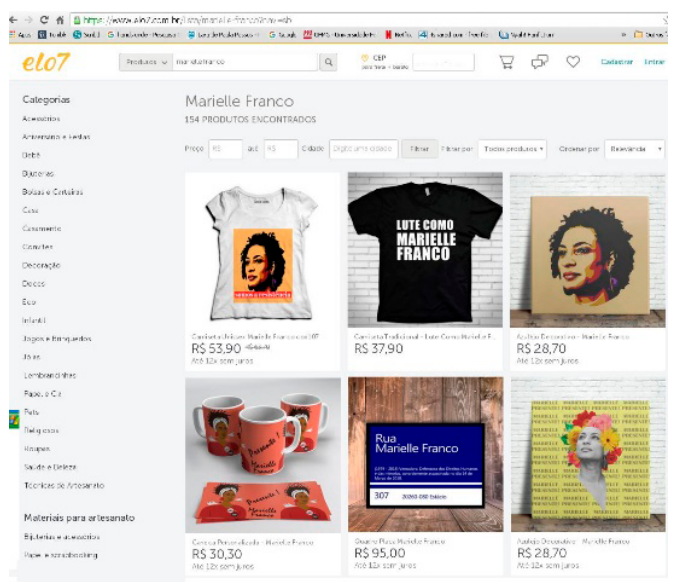

Fig. 36. Produtos vendidos contendo a imagem de Marielle, 2019.

Fonte: Site 7Elo.

Essa conversão capital gera também uma dissonância em termos de discurso quando são observados os locais de fala. No que tange à produção local/artesanal e em baixa escala,

3 Informações obtidas a partir de entrevista com testemunha ocular do acontecimento. 
é possível pensar em um ganho positivo: a disseminação de sua mensagem. Porém, os agentes discursivos já não são mais unicamente as vozes periféricas, mas grupos detentores de um poder hegemônico que lhes permite alcançar outros patamares de consumo e lucro com a produção em massa de itens cujo preço muitas vezes não é acessivel àquelas pessoas que mais se identificam com o conteúdo produzido. É o que ocorre no exemplo ilustrado pela FIGURA 35, em que o estilista Ronaldo Fraga usa a imagem de Marielle para promover sua linha de roupas com discurso engajado, porém, incoerentemente constrói algo a ser consumido por uma elite branca cujas vivências e lugares de fala são muitas vezes antagônicos aos de Marielle.

A apropriação capitalista, portanto, além da apropriação simbólica mobiliza também a esfera mercadológica, na qual há interesse monetário por trás da utilização desses elementos identitários enquanto produto a ser vendido e consumido. A eficácia dessa mercantilização está diretamente relacionada ao esvaziamento de seus significados particulares, posto que o objetivo primordial é atingir o nível máximo de aproveitamento a partir do alcance cada vez maior desses produtos. É necessário ampliar o nicho de mercado para garantir maior consumo. $\mathrm{O}$ aumento de um produto no mercado (FIGURA 36), no entanto, dilui consideravelmente seu impacto em relação ao consumidor (oferta e demanda). Se os movimentos de resistência se apoiam na potência de choque de uma figura combativa para construir um engajamento (como no caso da figura da Marielle enquanto materialização de violências silenciadas), a saturação dessa imagem no mercado banaliza sua referenciação, substituindo o choque pela normatização. A dessensibilização causada pela hiperexposição desfavorece as lutas identitárias ao passo que contribui para manutenção do sistema capitalista e colonial.

\section{Sementes: a resistência poética e política de mulheres negras no Brasil pós-Marielle}

A resistência de mulheres negras vem de longe, muito antes de qualquer bala achada ou perdida. Trata-se, pois, de um projeto coletivo, amplo e contínuo de emancipação e transformação social que tem orientado a fala e a ação de muitas vozes negras femininas.

Essa resistência segue necessária pelo constante luto por cada Cláudia, Luana, Marisa, Ágatha ${ }^{4}$ e tantas outras cujos nomes não se enunciam. Com a partida precoce e violenta de Marielle, reacendeu-se a chama dessa antiga luta, que pode ser observada a partir da eclosão de diversos coletivos, instalações artísticas, movimentos e eventos em sua memória. Livros, concursos literários, apresentações de trabalhos, artigos e diversos outros mosaicos produtivos foram pululando ao longo destes dois anos de denúncias, fazendo-se ver que, assim como foi vista, semente foi para germinar várias conquistas, em diferentes âmbitos. Dentre estes, um de maior destaque foi, sem dúvida, o âmbito da política:

Em 2019, o Brasil apresenta 51\% a mais de mulheres na Câmara dos Deputados, se considerarmos o número de mulheres eleitas para essa casa legislativa para a legislatura de 2014-2018. [...] O número de mulheres eleitas em 2018 para a Câmara é, por um lado, motivo para celebrarmos e, por outro, denuncia mais uma vez a gigantesca desigualdade de gênero que permeia os centros institucionais do poder político brasileiro. Somando-se as duas casas legislativas, Câmara e Senado, temos 567 vagas que serão ocupadas por apenas 84 mulheres na próxima legislatura. As mulheres são, no entanto, a maioria do eleitorado - 51,9\%, e quase a metade dos filiados a partidos políticos 44,3\% (TSE, 2018) (Silva 2019: 56).

Preocupadas com a apresentação de outras formas de administração diplomática e estratégias inovadoras para políticas

4 Claudia Silva Ferreira, 38 anos, auxiliar de limpeza, morta arrastada por carro da Polícia Militar, 16 de março de 2014. Luana Barbosa dos Reis, 34 anos, lésbica, pobre e negra, morta após ser espancada por PMs, 13 de abril de 2016. Marisa de Carvalho Nóbrega, diarista e vendedora, 48 anos, morta após levar coronhada de fuzil de policial do Bope, 7 de outubro de 2017. Ágatha Vitória Sales Félix, criança negra, 8 anos. Morta por tiro de fuzil nas costas dentro de kombi, voltando para casa da escola no Complexo do Alemão, 20 de setembro de 2019. 
identitárias, as mulheres negras rompem com uma esfera tradicionalmente branca, rígida e patriarcal (Silva 2019: 58) ao construírem suas campanhas e programas de governo. Com a eleição de mulheres negras, periféricas, LGBTQIA+, algumas ocupando pela primeira vez cargos historicamente delegados a homens brancos, podemos ver a mudança, ainda que lenta, a caminho de uma representatividade governamental mais justa, mesmo com a onda conservadora que emerge nos últimos anos no país. Neste processo, a produção de material bibliográfico referente ao caso (Cavaca \& Alves 2019; Danin, Carvalho Júnior \& Reis 2018; Fernandes \& Carvalho 2018; Guida \& Sigiliano 2018; GuimarãesSilva 2018; Nuñez et al. 2018; Oeiras et al. 2018; Schirmer \& Dalmolin 2018; Rocha 2018; Silva 2019; Souza 2019) serve não somente para que se mantenha viva uma memória, mas, principalmente, para que se construam pensamentos críticos acerca de um episódio cujo impacto segue alastrando-se por diversas configurações e interações.

\section{Arqueopoesia?}

Não é difícil ligar a arqueologia aos diversos aspectos relacionados ao caso Marielle Franco, em vista das corpografias urbanas (Jacques 2008) e das relações expressas a partir de tantos grafismos rupestres (Costa 2015; Endo 2009; Horta 1997) espalhados mundo afora. Mas, a partir das relações com teorias mais recentes, é possível observar também o engajamento de uma visão arqueológica que se mistura com a própria trajetória de vida da cientista (Million 2005). Um lugar onde pesquisador(a) e pesquisada não estão tão distantes, e, de uma certa maneira, o subalterno fala (Spivak 2010).

Enquanto fazia essa pesquisa, afetei-me diversas vezes pela figura de Marielle, sua memória e suas materialidades. As dores e belezas de cada uma de suas sementes foram germinando, por fim, no trabalho apresentado aqui. A arqueologia é, portanto, um meio de se conhecer, saber, mas também lembrar, sentir.
Ainda que construído de forma tradicional no que tange à apresentação dos dados e dos tópicos, a lógica motriz que norteia esta escrita está pautada no engajamento que tenho com quem sou e com tantas outras que me cercam, nas quais me espelho, até aqui. Olhar para um corpo negro feminino de luta que ousou romper as barreiras do racismo e do sexismo sistêmico para alçar voo em prol de si e de dias melhores convoca meu olhar para dentro de mim mesma, existência tão similar e ao mesmo tempo tão distante, da sujeita de pesquisa apresentada aqui.

Este texto se inicia com um poema, pois foi por meio da poética que a primeira palavra envolvendo este levantamento surgiu. Uma necessidade gritante de um ser mulher-negracientista de não se ver tripartida e de poder falar das coisas que me inquietam dentro e fora do meio acadêmico. Como a arqueologia chega nas pessoas? Por que não ela estaria em todo lugar? E, estando em todo espaço onde há matéria, por que não dentro da poesia? A utilização da linguagem poética enquanto recurso metodológico no fazer arqueológico, e não apenas como apreciação artística ou elemento estético, embasado nos conceitos de escrevivência (Evaristo 2007) - escrita que se retroalimenta com a vivência posto serem aspectos indissociáveis, recorrentemente separados pela lógica colonizada de se produzir - e o pretuguês (Gonzáles 1988) - forma de se comunicar construída ao longo da diáspora, mescla que surge (principalmente pelas vozes femininas) também como forma de reação à colonialidade e que diz respeito à maneira como as informações são passadas, bem como à herança lexical e linguística que alicerça grande parte das comunicações populares, em especial a de pessoas afrodescendentes -, que muito conversam com o contexto de poesia marginal e discussões já existentes de uma antropoética (Magni et al. 2018), foi o sustentáculo da construção que se fez até aqui.

Ao navegar pelos vestígios de memórias, pelos pedaços de histórias e pelas narrativas em disputa, pude sentir a importância da luta, a potência material e discursiva que Marielle Franco carrega em cada menção, em cada 
esquina. Aprendi a ler algumas entrelinhas que se amarram a seu percurso e pude me aproximar de uma compreensão um pouco melhor da carga política do que está em jogo em cada construção e destruição de narrativa. Um fazer científico engajado, situado e afetado quebra a falácia da neutralidade e deixa aberto o convite à possibilidade de construir outras formas de fazer ciência, viver ciência e construir arqueologia. Por fim, termino com uma carta escrita em 14 de março de 2018, como forma de dar a ver retalhos da poética desse sentir que permeou todo este caminho:

"Eu precisei de um mês pra ter coragem de escrever pra você.

E ao longo desse longo mês tudo foi tão contido, sustenido. E eu contigo. A mente voltava ao seu rosto cada vez que alguém falava alguma coisa (realmente presente). Cada homenagem, cada escrita, cada fotografia e só o que eu tinha era uma vontade inerente, quase irrefreável de sair dali. De parar de me ver refletida em cada imagem do seu rosto de mulher, negra bissexual, de luta. Eu só quis sumir. A breve menção do seu nome engatilhava em mim um desespero que, ainda que muito educado, muito contido, trazia consigo uma vontade desesperada de chorar ainda dá. Porque dói.

Dói o descaso de toda essa gente, dói admitir a minha parte nesses percalços, dói as mentiras, dói o uso malcuidado do seu nome, dói o desrespeito à sua lembrança, dói não ter o poder de parar esses recados do Estado. Dói saber que eles tornarão a acontecer. Não foi só com você.

A verdade é que eu não sei o que lhe dizer. Dizer o quê? Se na minha mente esse mês passou como um filme de terror a escancarar todas as minhas fraquezas. A puir com veemência esse fio tênue de sanidade.
Eu rio, sequei um pouco depois da sua partida. E tem dado um medo de tentar desaguar, transbordar. Porque parece que tudo é uma questão de abrir a porta, abrir a porta para a loucura entrar.

Eu demorei um mês para te escrever porque eu sinto raiva. Eu fico farta de pensar como as pessoas estão usando a sua imagem, abusando dessa liberdade (para todos os lados), e eu não quero me igualar. Eu tenho por você um carinho grande reservado àquelas que eu não conheci em vida, e um respeito enorme destinado às ancestrais, aquelas que vieram antes de mim, aquelas que eu nem sei o nome e nunca saberei, as que os olhos não me permitem ver o meu eu refletido. Mas que existiram, que resistiram e que nos carregaram, eu e você até aqui. Talvez eu demore mais um mês para escrever de novo, e talvez depois de mais esse mês a minha casca já esteja um pouco mais forte e eu consiga presenciar o seu nome sem revolta. Revolta por você ter sido mandada embora. Revolta por junto já terem ido tantas e tantos de nós.

Mas não pense que eu penso em você apenas como um corpo vazio num carro alvejado, que poderia ser eu se algum dia eu tiver como você a ousadia de alcançar tudo pelo que lutei na vida. Não, não cabe só tristeza e nostalgia na sua memória. A sua vida nos deu coragem, moveu milhares, reacendeu faíscas. E aquele fio (lá atrás) de sanidade tenta se manter inteiro muito apoiado nessa esperança que brotou da sua flor despedaçada regada de sangue. Você criou, multiplicou e fortaleceu raízes.

Eu demorei um mês para te escrever, e agora eu sinto que tudo isso caberia no resumo simples: eu sinto muito. Eu nem te conheço, mas te respeito. Eu te amo e te agradeço, eu nunca te esqueço, Marielle Franco."

Marielle Vive!

PASSOS, Laura de Paula. Within me lives every Marielle Franco: repression, resistance, archaeopoetry and the materiality of black women experiences. R. Museu Arq. Etn. 35: 79-102, 2020.

Abstract: Following the murder of black, city counselor, sociologist, feminist and human rights activist Marielle Franco on March 14, 2018, various manifestations of 
Vive em mim toda Marielle Franco: repressão, resistência, arqueopoesia e a materialidade das vivências de mulheres negras R. Museu Arq. Etn., 35: 79-102, 2020.

repression and resistance involving her image began to erupt. The case also triggered a greater movement of the production and circulation of materials (physical or digital) involving the genocide of black people and the femicide that happens at a national level that particularly affects black women. This paper analyzes this specific phenomenon as a case study, addressing in a broader way the material panorama that involves the experiences of black women from an anthropological, archaeological, and archaeopoetic point of view regarding repression and resistance issues.

Keywords: Archaeology; Archaeopoetry; Repression and resistance; Decoloniality.

\section{Referências bibliográficas}

Akotirene, C. 2018. O que é interseccionalidade? Letramento, São Paulo.

Bruno, M.C.O. 1996. Museus de arqueologia: uma história de conquistadores, abandono e mudanças. Revista do MAE 6: 293-313.

Câmara dos Deputados. 2018a. Feminicídio cresce entre mulheres negras e indígenas e diminui entre brancas, aponta pesquisadora. Disponível em: $<$ https://bit.ly/34g2bIi>. Acesso em: 17/05/2019.

Câmara dos Deputados. 2018b. Sistema carcerário brasileiro: negros e pobres na prisão. Disponível em: <https://bit.ly/3m8loRZ>. Acesso em: 17/05/2019.

Carta Capital. 2017. Atlas da Violência 2017: negros e jovens são as maiores vítimas. Disponível em: $<$ https://bit.ly/3dIrKov>. Acesso em: 17/05/2019.

Carvalho, R.A. 2013. Quando as relações se expressam nos muros. Ponto Urbe 13: 1-18.

Cavaca, S.D.; Alves, G.S. 2019. Mulheres no território político: Marielle Franco, marcas narrativas e estratégias de silenciamento. In: Anais do $24^{\circ}$ Intercom, 2019, Vitória.

Costa, C. 2018. Delegado de Pernambuco é afastado após postagens sobre Marielle Franco. Disponível em: <https://glo.bo/3m30CmT>.

Acesso em: 20/09/2019.
Costa, T.A.P. 2015. Relação entre grafite, pichação e arte rupestre. Disponível em: <https://bit. ly/3dEi1PO>. Acesso em: 20/06/2019.

Danin, R.A.; Carvalho Júnior, J.G.; Reis, T.R. 2018. Racismo discursivo: o caso Marielle Franco e a cobertura da mídia internacional. Methaodos: Revista de Ciencias Sociales 6: 279-289.

Deister, J. 2018. Manifestações em solidariedade a Marielle Franco acontecem no país e no mundo. Disponível em: <https://bit.ly/3m2vtjn $>$. Acesso em: 12/06/2019.

Dias, M.B. 2018. O assassinato de Marielle Franco. Jornal de Relações Internacionais 2: 1-2.

Endo, T.S. 2009. A pintura rupestre da pré-história e o grafite dos novos tempos. Trabalho de conclusão de curso. Universidade de São Paulo, São Paulo.

Evaristo, C. 2007. Da grafia-desenho de minha mãe, um dos lugares de nascimento de minha escrita. In: Alexandre, M.A. (Org.). Representações performáticas brasileiras: teorias, práticas e suas interfaces. Mazza, Belo Horizonte, 16-21.

Fernandes, S.F.; Carvalho, L.G. 2018. Análise semiótica de mídia cartaz no caso Marielle. Verbum 7: 125-136.

Ferreira, H.B.P. 2018. Retrato da desigualdade: brancos têm dois anos a mais de estudo. 
Disponível em: <https://glo.bo/2H8sQ0Z > Acesso em: 17/05/2019.

Franco, M. 2017. A emergência da vida para superar $\mathrm{o}$ anestesiamento social frente à retirada de direitos: o momento pós-golpe pelo olhar de uma feminista, negra e favelada. In: Bueno, W. et al. (Orgs.). Tem saída? Ensaios críticos sobre o Brasil. Zouk, Porto Alegre.

Franco, M. 2018. UPP - a redução da favela a três letras: uma análise da política de segurança pública do estado do Rio de Janeiro. N-1, São Paulo.

G1. 2018. Conselho arquiva processo de deputado que divulgou fake news sobre Marielle. Disponível em: <https://glo.bo/37rOkQX >. Acesso em: 20/09/2019.

G1 Rio. 2018. No Rio, Malala Yousafzai posa ao lado de desenho de Marielle Franco. Disponível em: $<$ https://glo.bo/3j8AncY>. Acesso em: 18/10/2020.

Gonzáles, L. 1988. A categoria político-cultural de amefricanidade. Tempo Brasileiro 92-93: 69-82.

Guida, V.; Sigiliano, D. 2018. Competência midiática e informação: análise dos interagentes na página do Jornal O Globo em relação ao caso Marielle Franco. Trabalho de curso. Universidade Federal de Juiz de Fora, Juiz de Fora.

Guimarães-Silva, P. 2018. Marielle e a representatividade da vida que carrega o signo da morte. In: Marques, Ângela C. S. (Org.). Vulnerabilidades, justiça e resistências nas interações comunicativas. Fafich, Belo Horizonte, 60-70.

Gustafson, J. 2019. Brasil caminha para liderar ranking mundial da violência contra mulher. Disponível em: $<$ https://bit.ly/3kfVLhR $>$. Acesso em: 17/05/2019.

Haber, A. 2011. Nometodología payanesa: notas de metodología indisciplinada (con comentarios de Henry Tantalean, Francisco Gil García y Dante Angelo). Revista Chilena de Antropología 23: 9-50.
Haraway, D. 1995. Saberes localizados: a questão da ciência para o feminismo e o privilégio da perspectiva parcial. Cadernos Pagu 5: 7-41.

Horta, A.I. 1997. Pinturas rupestres urbanas: uma etnoarqueologia das pichações em Belo Horizonte. Revista de Arqueologia 10: 143-161.

IBGE. 2010. Estatísticas de gênero. Disponível em: $<$ https://bit.ly/34b9ZLh>. Acesso em: 19/07/2019.

IG São Paulo. 2018. Um dos grafites feitos em homenagem a Marielle Franco foi vandalizado na madrugada desta quarta (19) e ação é flagrada por câmeras de segurança. Disponível em: $<$ https:// bit.ly/3kflzrR >. Acesso em: 18/10/2020.

Jacques, P.B. 2008. Corpografias urbanas. Vitruvius 93.

Leslie, L. 2018. Munição usada para matar Marielle é de lotes vendidos para a Polícia Federal. Disponível em: <https://glo.bo/2T3ayAm>. Acesso em: 16/03/2018.

Magni, C.T. et al. 2018. Desenhar para quê? Experimentações antropoéticas em pesquisa e ensino. Áltera: Revista de Antropologia 1: 136-165.

Marques, J.V. 2018. Candidatos do partido de Bolsonaro quebram placa que homenageava Marielle no Rio. Disponível em: $<$ https://bit. ly/2HfCQW6>. Acesso em: 15/10/2019.

Marreiro, F. 2019. Nome de Bolsonaro aparece em investigação do caso Marielle, que pode ir para o STF. Disponível em: <https://bit.ly/3oc4F2m >. Acesso em: 30/10/2019.

Million, T. 2005. Developing an aboriginal archaeology: receiving gifts from the white buffalo calf woman. In: Bruchac, M.; Hart, S.; Wobst, H.M. (Eds.). Indigenous archaeologies: a reader on decolonization. Routledge, New York, 189-192.

Nuñez, I. et al. 2019. A administração da morte de Marielle Franco por parte do Estado. Dignidade Re-Vista 4: 62-78. 
Vive em mim toda Marielle Franco: repressão, resistência, arqueopoesia e a materialidade das vivências de mulheres negras R. Museu Arq. Etn., 35: 79-102, 2020.

O Globo. 2018a. Morte de Marielle Franco gera protestos ao redor do mundo. Disponível em: $<$ https://glo.bo/31qWwwW>. Acesso em: 20/09/2019.

O Globo. 2018b. Polícia descobre que arma usada para matar Marielle e Anderson foi uma submetralhadora. Disponível em: <https://glo. bo/2T9u6mJ>. Acesso em: 18/10/2020.

Oeiras, T. et al. 2018. Propagação de fake news pelo Movimento Brasil Livre: caso Marielle Franco. In: Anais do $20^{\circ}$ Congresso de Ciências da Comunicação, 2018, Juazeiro.

Passos, L.; Mota, M. 2019. Ocupar e resistir: uma reflexão arqueológica sobre as intervenções gráficas na Fafich-UFMG pós-ocupações. Revista Três Pontos 15: 1-18.

Perez, F. 2018. Marielle ofereceu ajuda a dezenas de famílias de policiais no RJ. Disponível em: $<$ https://bit.ly/3jbz1Ox>. Acesso em: 20/09/2019.

Ribeiro, D. 2019. Lugar de fala. Pólen, São Paulo.

Ribeiro, L. 2017. Crítica feminista, arqueologia e descolonialidade. Revista de Arqueologia 30: 210-234.

Rocha, L.M. 2018. A vida e as lutas de Marielle Franco. Em pauta 16: 274-280.

Saconi, J.P. 2018. Cabo da PM e vice-presidente da $\mathrm{OAB}$ de Salto brincam com "sanduíche Maria da
Penha" citando Marielle. Disponível em: <https:// glo.bo/37paeEu>. Acesso em: 20/09/2019.

Schirmer, L.C.; Dalmolin, A.R. 2018. Discurso de ódio biopolítico no caso Marielle Franco. In: Anais do $1^{\circ}$ Congresso Nacional de Biopolítica e Direitos Humanos, 2018, Ijuí.

Silva, A.F.L. 2019. "Marielle virou semente": representatividade e os novos modos de interação política da mulher negra nos espaços institucionais de poder. Revista Sociologias Plurais 5: 52-75.

Silva, G.J. 2014. Conceituações teóricas: esquerda e direita. Humanidades em Diálogo 6: 149-162.

Souza, D.P.J. 2019. Sementes - com você ando melhor: o legado de Marielle Franco como agente incentivador da representatividade das mulheres negras nos espaços políticos. In: Bispo, C.; Gostinski, A.; Martins, F. (Orgs.). Estudos feministas: por um direito menos machista. Tirant Brasil, Rio de Janeiro, v. 4, 77-92.

Souza, R.A. 2013. Pixações sob a ótica da arqueologia urbana. Revista de Arqueologia Pública 8: 135-156.

Spivak, G.C. 2010. Pode o subalterno falar? Editora UFMG, Belo Horizonte.

Tarouco, G.S.; Madeira, R.M. 2013. Partidos, programas e o debate sobre esquerda e direita no Brasil. Revista de Sociologia e Política 21: 149-165. 